Article

\title{
Impacts of Anthropogenic Disturbance on Vegetation Dynamics: A Case Study of Wadi Hagul, Eastern Desert, Egypt
}

\author{
Ramadan Bedair ${ }^{1}$, Amira A. Ibrahim ${ }^{2, *}$, Amal A. Alyamani ${ }^{3}$, Salman Aloufi ${ }^{3}$ and Samah Ramadan ${ }^{4}$ \\ 1 Department of Botany and Microbiology, Faculty of Science, Al-Azhar University, Nasr City, \\ Cairo 11884, Egypt; RamadanIbrahim.211@azhar.edu.eg \\ 2 Department of the Plant Protection and Biomolecular Diagnosis, Arid Lands Cultivation Research \\ Institute (ALCRI), City of Scientific Research and Technological Applications (SARTA, City), \\ New Borg El Arab City 21934, Egypt \\ 3 Department of Biotechnology, Faculty of Sciences, Taif University, P.O. Box 11099, Taif 21944, Saudi Arabia; \\ a.yamani@tu.edu.sa (A.A.A.); s.aloufi@tu.edu.sa (S.A.) \\ 4 Botany Department, Faculty of Science, Mansoura University, Mansoura 35516, Egypt; \\ samahmahmoud@mans.edu.eg \\ * Correspondence: amiranasreldeen@yahoo.com; Tel.: +20-106-667-7539
}

check for updates

Citation: Bedair, R.; Ibrahim, A.A.; Alyamani, A.A.; Aloufi, S.; Ramadan, S. Impacts of Anthropogenic

Disturbance on Vegetation Dynamics: A Case Study of Wadi Hagul, Eastern Desert, Egypt. Plants 2021, 10, 1906. https://doi.org/10.3390/ plants10091906

Academic Editor:

Daniel Sánchez-Mata

Received: 6 July 2021

Accepted: 9 September 2021

Published: 14 September 2021

Publisher's Note: MDPI stays neutral with regard to jurisdictional claims in published maps and institutional affiliations.

Copyright: (c) 2021 by the authors. Licensee MDPI, Basel, Switzerland. This article is an open access article distributed under the terms and conditions of the Creative Commons Attribution (CC BY) license (https:/ / creativecommons.org/licenses/by/ $4.0 /)$.

\begin{abstract}
Irresponsible human interventions, encroachment of natural habitats, and climate change negatively affect wildlife. In this study, the effects of human influence on Wadi Hagul, an unprotected area in the north of the Egyptian Eastern Desert that has recently been subjected to blatant encroachments of vegetation, were studied. The most important of these threats is the construction of the new road Al-Galala-Wadi Hagul-Zafarana. In Wadi Hagul, 80 species are reported in this study; the most represented plant families are Asteraceae (15 species) and Brassicaceae (6 species). Perennial, chamaephyte and Saharo-Arabian species were recorded in the highest percentage. Detrended canonical correspondence analysis showed that latitude, longitude, altitude, silt, sand contents, $\mathrm{pH}$, and $\mathrm{CO}_{3}{ }^{2-}$ content are the factors that have the highest effect on vegetation distribution in the studied stands. Several invasive and alien species such as Euphorbia prostrata have been listed; these species typically have a negative effect on native species. The Soil Adjusted Vegetation Index (SAVI) indicated a decrease in plant cover during the study period, as compared to previous years. In 2013 and 2020, SAVI ranged from -0.02 to 0.42 and from -0.18 to 0.28 , respectively. Recently, the violation and destruction of wildlife have increased, therefore, preserving it along with general biodiversity has become an urgent necessity.
\end{abstract}

Keywords: plant diversity; anthropogenic impacts; vegetation dynamics; wildlife; Wadi Hagul; DCCA; SAVI

\section{Introduction}

Land degradation and vegetation reduction caused by external stresses, affect biodiversity and natural ecosystems and the numerous services they provide [1]. Environmental deterioration, habitat changes, inappropriate vegetation management, translocation, fragmentation, and deforestation modify biotic and abiotic ecosystem components, resulting in changes in ecological processes such as vegetation dynamics [2-4]. Overgrazing, road building, overharvesting, solid wastes, salinization, industrialization, urbanization, and military activities are considered to be the main anthropogenic activities that lead to changes and transformation of vegetation and natural habitat loss in arid and semi-arid environments [5-7].

In terrestrial ecosystems, climate and land cover changes such as cover, height, biomass, relative humidity, soil temperature, moisture, fertility, and erosion affect the structural properties of vegetation [8]. Biodiversity decline is influenced by various types of human activities, including land cover changes, the introduction of invasive species, 
overexploitation, and pollution [9-11]. Alteration of vegetation growth is the result of climate variation, and human activities can modify atmosphere-biosphere interaction, causing changes in the hydrological cycle, either directly or indirectly [12-14].

Environmental issues, including soil fertility decline, heavy winds, increase in the evaporation rate, high temperature, and heavy rainfall, lead to dramatic changes in plant species community structure $[7,15,16]$. Ecosystem services and biodiversity contribute approximately $57 \%$ of gross domestic production [17], therefore, there is a pressing need to save biodiversity, especially endangered species through convert these locations to protected areas [18]. There are a variety of approaches that are able to reverse biodiversity loss, ranging from economic, through ecological, to ethical [19].

Human pressures in Africa, include agricultural and pasture activities, illegal timber harvesting, and bush fires. All of these stresses have a negative impact on the plant ecosystem [20]. From the middle of the last century, the human population of the earth doubled [21]. Population growth and urbanization are the most important causes of ecosystems collapse [22]. Rapid population growth leads to many problems such as fire prevalence, air pollution, light pollution, loss of genetic diversity, the prevalence of invasive species, and wildlife destruction [23]. Human activities, through the civilizational and agricultural expansion and by the destruction of natural habitats, have increased extinction rates up to 500 times [24] (Baillie et al., 2004). Over the ages, human activities have caused three powerful waves of extinction [25]. It is estimated that nearly 8390 plant species are listed as endangered [26]. Approximately $32 \%$ of the existing plant species are classified as either critically endangered or extinct [27], nearly $20 \%$ being extinct because of human activities [28]. In China, nearly $11 \%$ of the plant species that were evaluated are extinct [29].

Species with a narrow distribution range are more likely to be lost, while widespread species are more likely to survive [30]. Some wild plants have adapted to the conditions and survived in their natural habitats [31]. However, invasive species spread causes disturbance in communities and may lead to the extinction of endemic and native species [32].

Anthropogenic activities are causing changes in natural plant communities in Egypt from ancient times through draining of lakes and marshes and reduction of species number in aquatic communities [33]. Remote sensing is one of the most unique techniques used for estimating environmental changes [34]. Some characteristics of vegetation detected using remote sensing techniques are photosynthetic activity, chlorophyll content, plant density, green leaf biomass, the leaf area index, and plant health [35]. The second factor that includes climatic measures includes air temperature and solar radiation [36-38]. SAVI is one of the most common vegetation indices used as a tool to discriminate vegetation covers [39]. SAVI can be used efficiently in arid regions [40]. In areas where vegetative cover is low (i.e., $<40 \%$ ) and the soil surface is exposed, the reflectance of light in the red and near-infrared spectra can influence vegetation index values. This is especially problematic when comparisons are being made across different soil types that may reflect different amounts of light in the red and near-infrared wavelengths (i.e., soils with different brightness values). The soil-adjusted vegetation index was developed as a modification of the Normalized Difference Vegetation Index (NDVI) to correct for the influence of soil brightness when vegetative cover is low [41]. The output of SAVI is a new image layer with values ranging from -1 to 1 . The lower the value, the lower the amount/cover of green vegetation [42].

A wadi is a natural depression on the earth's surface. Wadi Hagul is a morphotectonic depression located between Gebel Ataqa's southern scarps in the north and El-Galala El-Bahariya Plateau's northern scarp in the south. Wadi Hagul is one of the unprotected wadies in Egypt and is one of the most anticipated project areas in Egypt to alleviate congestion. As a result, several integrated development projects are being worked on that implement many critical infrastructure areas such as quarries, roads, power plants, mines, landfills, and resorts. The most important national project is the development of the northern part of the Gulf of Suez pipeline surcharge, implemented through the main track of the study area and its environment [43]. Three main sectors can be recognized based on 
the vegetation and geological aspects of Wadi Hagul: upstream, middle, and downstream. Two distinct plant communities can be found in the upstream section of Wadi Hagul's main channel: one is dominated by Zilla spinosa on elevated terraces of mixed deposits. The other is dominated by Launaea spinosa and represents a further stage in the building up of the wadi bed. In the middle section, Leptadenia pyrotechnica community occurs. In the downstream section, the vegetation is dominated by Hammada elegans with individuals of Launaea spinosa and Lygos raetam [44].

This paper focuses on Wadi Hagul, which has neither attained sufficient interest from intended responsible parts nor ecological studies, although it is considered an environment rich in various plants including a number of endangered plants, whereas other Eastern desert wadis of Egypt have received both interest and studies convenient for them. Therefore, the objective of this study is the estimation of vegetation cover in Wadi Hagul through the illustration of the relationship between environmental factors in the studied localities and the distribution of plant communities. The study also aimed at comparing vegetation changes and at testing new methods to record the reasons for changes in vegetation dynamics by calculating the temporal patterns of SAVI during 2013, 2015, and 2020 in Wadi Hagul, Eastern Egyptian Desert.

\section{Materials and Methods}

\subsection{Study Area}

Wadi Hagul lies between $32^{\circ} 09^{\prime} 32^{\prime \prime} \mathrm{E}$ and $32^{\circ} 17^{\prime} 27^{\prime \prime} \mathrm{E}$ and between $29^{\circ} 48^{\prime} 28^{\prime \prime} \mathrm{N}$ and $29^{\circ} 57^{\prime} 43^{\prime \prime} \mathrm{N}$, with an area of $350 \mathrm{~km}^{2}(0.16 \%$ of the Eastern Desert total area). The main canal of Wadi Hagul extends until it reaches the Gulf of Suez, with a width ranging from 6 to $10 \mathrm{~km}$ and a length of approximately $36 \mathrm{~km}$. Wadi Hagul is considered to be one of 15 wadies located on the Red Sea coast. It is situated $112 \mathrm{~km}$ west of Cairo, between Gebel Ataqa and the Kahaliya ridge [44]. Wadi Hagul is characterized by a dry desert climate with little rain, high temperatures, and a high evaporation rate. The three sections represent dry natural habitats inhabited mainly by xerophytic plants. The dominant species are Fagonia mollis, Echinops spinosus, and other xerophytic plants [45].

\subsection{Climate Data}

Climate data for the past 30 years (1990-2020) were extracted from www.meteoblue.com; accessed on 15 April 2021. They include mean maximum temperature $\left({ }^{\circ} \mathrm{C}\right)$, mean minimum temperature $\left({ }^{\circ} \mathrm{C}\right)$, precipitation $(\mathrm{mm})$, hot days $\left({ }^{\circ} \mathrm{C}\right)$, and cold nights $\left({ }^{\circ} \mathrm{C}\right)(\mathrm{T} \mathrm{S} 1)$. Wind direction and velocity $(\mathrm{km} / \mathrm{h})$ are provided in Figure $\mathrm{S} 2$.

\subsection{Floristic Study}

To estimate the vegetation cover in Wadi Hagul, 20 stands were chosen to represent different plant habitats in Wadi Hagul. A total of 20 stands were selected for the study of the vegetation of Wadi Hagul during the spring and summer seasons of 2019 and 2020. In each stand, four quadrates were chosen (quadrate area $=10 \mathrm{~m} \times 10 \mathrm{~m}=100 \mathrm{~m}^{2}$ ) (Table 1 and Figures 1 and 2). Vegetation cover was measured using visual estimation. Recorded plant species in all localities were identified, and life span was documented according to Boulos [46-50]. Life form and floristic category were recognized after Raunchier [51], Tutin et al. [52], and Davis [53].

\subsection{Soil Analyses}

Many soil factors were examined in order to determine the characteristics of the soil in the study area. From each stand, four soil samples were collected and merged to form a homogeneous and representative sample of a single locality. Fifteen soil factors were analyzed: soil texture (sand, silt, and clay), $\mathrm{pH}$, total dissolved salts, electrical conductivity, magnesium, calcium, sodium, potassium, chloride, bicarbonate, carbonate, sulfate, and organic carbon content. Soil texture was determined according to Estefan et al. [54] using a pipette method. Digital portable pH, TDS, and EC meters (Adwa ${ }^{\circledR}$, Adwa Instruments, 
Szeged, Hungry) were used to calculate $\mathrm{pH}$, total dissolved salts (T.D.S.), and electrical conductivity (E.C.). Magnesium and calcium were determined using a titration method according to Page et al. [55]. A flame photometer at wavelengths of 589 and $767 \mathrm{~nm}$ was used to determine sodium and potassium, respectively [54]. Chlorides, bicarbonates, and carbonates were determined using a titration method [56]. Sulfates were determined after Estefan et al. [54] using the turbid metric method. Organic carbon was determined using a titration method [57].

Table 1. Global Positioning System coordinates of the studied localities in Wadi Hagul.

\begin{tabular}{|c|c|c|c|c|c|c|c|}
\hline Stands & Latitude (N) & Longitude (E) & $\begin{array}{c}\text { Altitude } \\
\text { above Sea } \\
\text { Level (m) }\end{array}$ & Stands & Latitude (N) & Longitude (E) & $\begin{array}{c}\text { Altitude } \\
\text { above Sea } \\
\text { Level (m) }\end{array}$ \\
\hline 1 & $30^{\circ} 1^{\prime} 2.58345^{\prime \prime}$ & $32^{\circ} 5^{\prime} 29.5121^{\prime \prime}$ & 277 & 11 & $29^{\circ} 50^{\prime} 45.68^{\prime \prime}$ & $32^{\circ} 16^{\prime} 4.86^{\prime \prime}$ & 152 \\
\hline 2 & $29^{\circ} 59^{\prime} 33.13075^{\prime \prime}$ & $32^{\circ} 5^{\prime} 56.79499^{\prime \prime}$ & 295 & 12 & $29^{\circ} 51^{\prime} 39.19^{\prime \prime}$ & $32^{\circ} 15^{\prime} 43.54135^{\prime \prime}$ & 163 \\
\hline 3 & $29^{\circ} 58^{\prime} 49.0674^{\prime \prime}$ & $32^{\circ} 7^{\prime} 3.39269^{\prime \prime}$ & 307 & 13 & $29^{\circ} 49^{\prime} 35.08406^{\prime \prime}$ & $32^{\circ} 16^{\prime} 17.25956^{\prime \prime}$ & 131 \\
\hline 4 & $29^{\circ} 58^{\prime} 1.74144^{\prime \prime}$ & $32^{\circ} 8^{\prime} 38.88139^{\prime \prime}$ & 327 & 14 & $29^{\circ} 47^{\prime} 44.49253^{\prime \prime}$ & $32^{\circ} 16^{\prime} 35.06138^{\prime \prime}$ & 109 \\
\hline 5 & $29^{\circ} 57^{\prime} 19.91^{\prime \prime}$ & $32^{\circ} 9^{\prime} 58.45^{\prime \prime}$ & 286 & 15 & $29^{\circ} 47^{\prime} 7.80^{\prime \prime}$ & $32^{\circ} 15^{\prime} 59.88^{\prime \prime}$ & 132 \\
\hline 6 & $29^{\circ} 56^{\prime} 16.55599^{\prime \prime}$ & $32^{\circ} 10^{\prime} 52.53848^{\prime \prime}$ & 258 & 16 & $29^{\circ} 46^{\prime} 16.54^{\prime \prime}$ & $32^{\circ} 15^{\prime} 18.87^{\prime \prime}$ & 113 \\
\hline 7 & $29^{\circ} 55^{\prime} 38.91^{\prime \prime}$ & $32^{\circ} 11^{\prime} 37.12^{\prime \prime}$ & 243 & 17 & $29^{\circ} 45^{\prime} 6.97^{\prime \prime}$ & $32^{\circ} 14^{\prime} 49.35^{\prime \prime}$ & 89 \\
\hline 8 & $29^{\circ} 54^{\prime} 34.95031^{\prime \prime}$ & $32^{\circ} 12^{\prime} 30.83965^{\prime \prime}$ & 223 & 18 & $29^{\circ} 43^{\prime} 59.88^{\prime \prime}$ & $32^{\circ} 14^{\prime} 39.51^{\prime \prime}$ & 78 \\
\hline 9 & $29^{\circ} 53^{\prime} 55.03^{\prime \prime}$ & $32^{\circ} 13^{\prime} 17.35^{\prime \prime}$ & 213 & 19 & $29^{\circ} 43^{\prime} 0.09^{\prime \prime}$ & $32^{\circ} 15^{\prime} 5.75^{\prime \prime}$ & 65 \\
\hline 10 & $29^{\circ} 53^{\prime} 10.26654^{\prime \prime}$ & $32^{\circ} 14^{\prime} 15.37418^{\prime \prime}$ & 190 & 20 & $29^{\circ} 41^{\prime} 54.08515^{\prime \prime}$ & $32^{\circ} 15^{\prime} 7.61404^{\prime \prime}$ & 66 \\
\hline
\end{tabular}

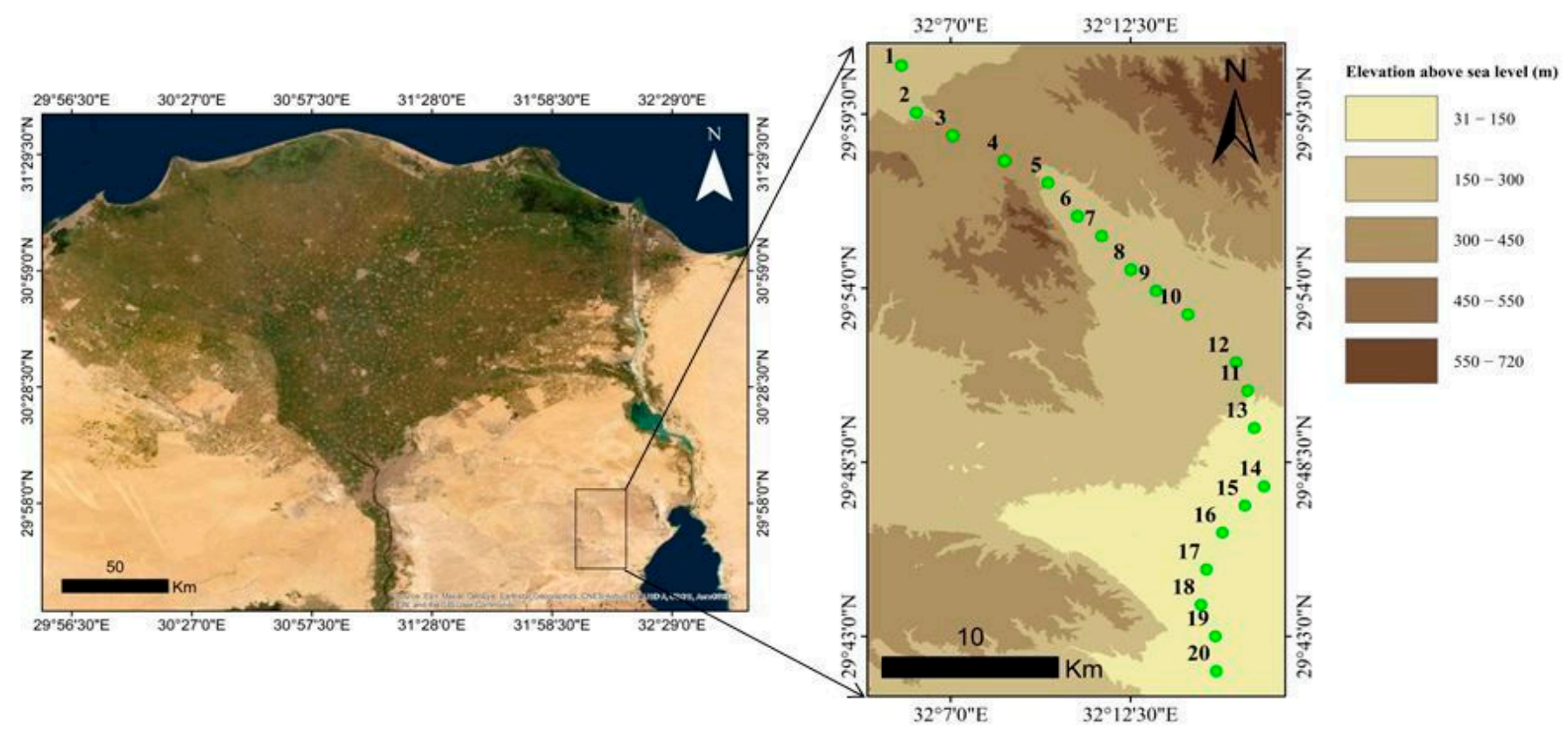

Figure 1. Location on the map showing the digital elevation model of Wadi Hagul. 


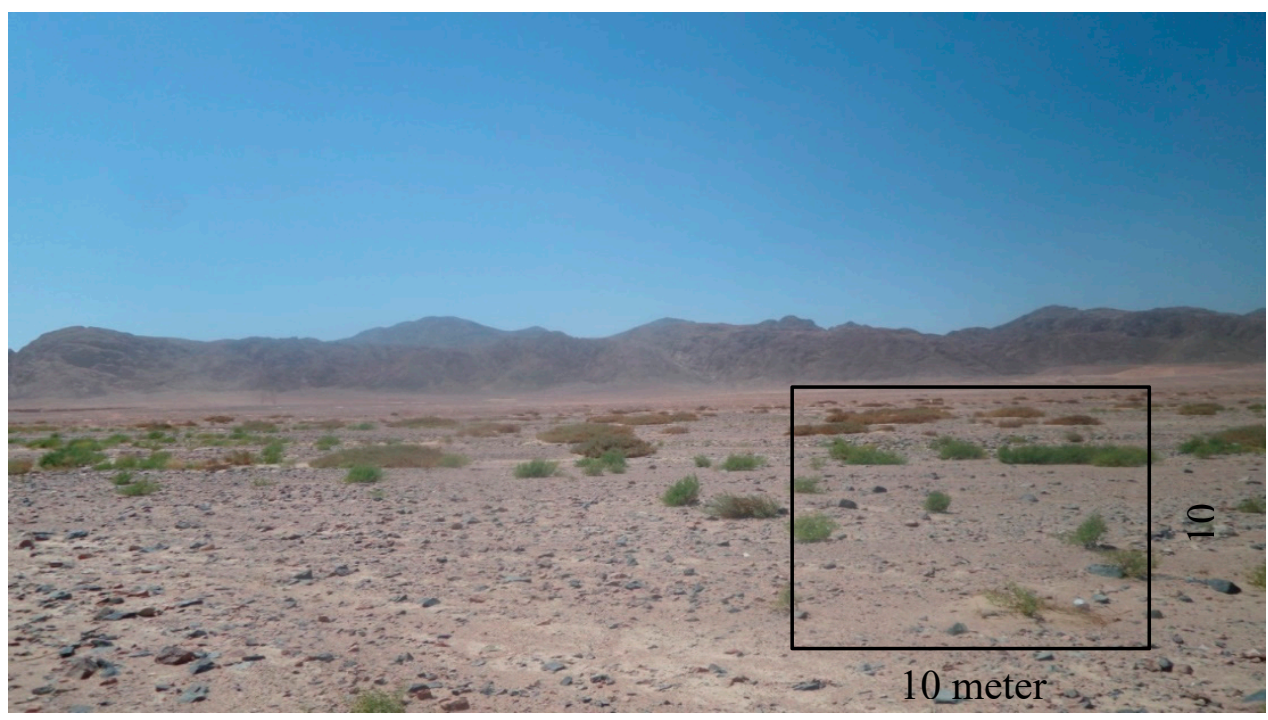

Figure 2. A quadrate with an area of $10 \mathrm{~m} \times 10 \mathrm{~m}$ in.

\subsection{Statistical Analyses}

Descriptive statistical measures (mean, median, standard deviation, range, minimum, maximum, and interquartile range) for different soil factors were determined using Sigmaplot ver. 12.5 .

Several biodiversity indicators were measured such as Shannon's and Simpson's diversity indices, species richness, and evenness were extracted using PC-ORD ver. 5 software [58]. Hills numbers were calculated using the R program.

To clarify the relationship between environmental factors, especially soil factors, the study area was divided into three areas: the beginning of the Wadi (stands 1 to 7 ), the middle (stands 8 to 14), and the end of the Wadi (stands 15 to 20). A detrended canonical correspondence analysis (DCCA) was performed using CANOCO ver. 4.5 and CanoDraw ver. $4.1[59]$.

\subsection{Vegetation Change}

To confirm the negative impact of human interventions on the vegetation cover in Wadi Hagul, SAVI was calculated in the study area during different years. Satellite images for 2013, 2015, and 2020 were obtained from the Landsat 8 satellite (Band 4 and Band 5) during the spring season using the website https://earthexplorer.usgs.gov/; accessed on 15 April 2021. Due to the position of the satellite in its orbit, haze, dust, and sun angle, satellite images have some defects which should be processed. Satellite images should be geometrically, atmospherically, and radiometrically corrected to become ready for extracting the required data. For that, satellite image processing software ENVI 5.3 and Arc GIS 10.5 were used to correct the collected satellite imageries. Soil Adjusted Vegetation Index (SAVI) was calculated according to the following equation:

$$
\text { SAVI }=((\text { Band } 5-\text { Band } 4) /(\text { Band } 5+\text { Band } 4+\mathrm{L})) \times(1+\mathrm{L})) .
$$

where, $\mathrm{L}=$ The amount of green vegetation cover (For example, 0.5 ).

Then the study area (Hagul) was extracted from the satellite images.

\section{Results}

\subsection{Floristic Composition}

A collection of 80 plant taxa, belonging to 30 families, was recorded in Wadi Hagul. The most represented plant families were Asteraceae, Brassicaceae, and Zygophyllaceae with $15(18.8 \%), 6(7.5 \%)$, and 5 species $(6.3 \%)$, respectively. Thirteen families (Amaranthaceae, Apiaceae, Capparaceae, Convolvulaceae, Cucurbitaceae, Ephedraceae, Malvaceae, 
Nitrariaceae, Orobanchaceae, Fabaceae, Plantaginaceae, Polygonaceae, and Rutaceae) were represented by one species (Table 2 and Figure 3).

Table 2. The list of species recorded in Wadi Hagul with their plant families, life span, life form, floristic category, and abbreviations.

\begin{tabular}{|c|c|c|c|c|c|c|}
\hline Species & Family & Life Span & Life Form & $\begin{array}{l}\text { Floristic } \\
\text { Category }\end{array}$ & Record & Abbreviation \\
\hline Blepharis attenuata Napper & \multirow{2}{*}{ Acanthaceae } & Pe. & Cha. & IR and SA & B & Ble att \\
\hline Blepharis edulis (Forssk.) Pers. & & Pe. & Cha. & SA and SZ & B & Ble edu \\
\hline Aizoon canariensis $\mathrm{L}$. & Aizoaceae & An. & The. & SA and SZ & A & Aiz can \\
\hline $\begin{array}{l}\text { Aerva javanica (Burm.f.) Juss. ex } \\
\text { Schult. }\end{array}$ & Amaranthaceae & Pe. & Cha. & SA and SZ & B & Aer jav \\
\hline Deverra tortuosa (Desf.) DC. & Apiaceae & Pe. & Cha. & SA & $\mathrm{A}, \mathrm{B}$ & Dev tor \\
\hline Calotropis procera (Aiton) W.T. Aiton & \multirow{4}{*}{ Asclepiadaceae } & Pe. & Pha. & SA and SZ & $\mathrm{A}, \mathrm{B}$ & Cal pro \\
\hline Cynanchum acutum L. & & Pe. & Hem. & Med, R, and ER & $\mathrm{A}, \mathrm{B}$ & Cyn acu \\
\hline $\begin{array}{c}\text { Leptadeniapyrotechnica (Forrsk.) } \\
\text { Decne. }\end{array}$ & & Pe. & Pha. & SA & $\mathrm{A}, \mathrm{B}$ & Lep pyr \\
\hline Pergularia tomentosa $\mathrm{L}$. & & Pe. & Cha. & SA & $\mathrm{A}, \mathrm{B}$ & Per tom \\
\hline $\begin{array}{l}\text { Achilleafragrantissima (Forssk.) Sch. } \\
\text { Bip. }\end{array}$ & \multirow{21}{*}{ Asteraceae } & Pe. & Cha. & SA and IR & $\mathrm{A}, \mathrm{B}$ & Ach fra \\
\hline Artemisia judaica L. & & Pe. & Cha. & SA & A & Art jud \\
\hline Atractylis carduus (Forssk.) C.Chr. & & Pe. & Hem. & ME and SA & A & Atr car \\
\hline Bidens pilosa $\mathrm{L}$. & & An. & The. & PAN & A & Bid pil \\
\hline Centaurea aegyptiaca L. & & Bi. & The. & SA & $\mathrm{A}, \mathrm{B}$ & Cen aeg \\
\hline Conyza aegyptiaca (L.) Dryand. & & An. & The. & Med & $\mathrm{A}, \mathrm{B}$ & Con aeg \\
\hline Conyza bonariensis (L.) Cronquist & & An. & The. & Med & $\mathrm{A}, \mathrm{B}$ & Con bon \\
\hline Cotula cinerea Del. & & An. & The. & SA & A & Cot cin \\
\hline Echinops spinosus L. & & Pe. & Hem. & Med and SA & $\mathrm{A}, \mathrm{B}$ & Ech spi \\
\hline Ifloga spicata (Forssk.) Sch. Bip. & & An. & The. & SA & A & Ifl spi \\
\hline Iphiona mucronata (Forssk.)Asch. & & Pe. & Cha. & SA & $\mathrm{A}, \mathrm{B}$ & Iph muc \\
\hline Launaea capitata (Spreng)Dandy & & Bi. & The. & SA and SZ & A & Lau cap \\
\hline Launea nudicalus (L.) Hook. f. & & Pe. & Hem. & SA & $\mathrm{A}, \mathrm{B}$ & Lau nud \\
\hline $\begin{array}{l}\text { Launea spinosa (Forssk.) Sch. Bip. ex } \\
\text { Kuntze. }\end{array}$ & & Pe. & Cha. & SA & $\mathrm{A}, \mathrm{B}$ & Lau spi \\
\hline $\begin{array}{l}\text { Nauplius graveolens } \\
\text { (Forssk.)Wilklund }\end{array}$ & & Pe. & Cha. & SA & $\mathrm{A}, \mathrm{B}$ & Nau gra \\
\hline Pluchea dioscoridis (L.) DC. & & Pe. & Pha. & SA and SZ & $\mathrm{A}, \mathrm{B}$ & Plu dio \\
\hline Pulicaria undulata (L.) C.A.Mey. & & Pe. & Cha. & SA nd SZ & $\mathrm{A}, \mathrm{B}$ & Pul und \\
\hline Reichardia tingitana (L.) Roth & & An. & The. & Med and IR & B & Reitin \\
\hline Senecio glaucus L. & & An. & The. & Med, IR, andSA & $\mathrm{A}, \mathrm{B}$ & Sen gla \\
\hline Sonchus oleraceus L. & & An. & The. & COSM & $\mathrm{A}, \mathrm{B}$ & Son ole \\
\hline Volutaria lippii (L.) Cass. Ex Maire. & & An. & The. & SA & $\mathrm{A}, \mathrm{B}$ & Vol lip \\
\hline
\end{tabular}


Table 2. Cont.

\begin{tabular}{|c|c|c|c|c|c|c|}
\hline Species & Family & Life Span & Life Form & $\begin{array}{l}\text { Floristic } \\
\text { Category }\end{array}$ & Record & Abbreviation \\
\hline Anchusa humilis (Desf.) I. M. Johnst. & \multirow{4}{*}{ Boraginaceae } & An. & The. & Med and SA & B & Anc hum \\
\hline Heliotropiumarabinense Fresen. & & Pe. & Cha. & SA & $\mathrm{B}$ & Hel ara \\
\hline $\begin{array}{l}\text { Heliotropium digynum (Forssk.) } \\
\text { Christens }\end{array}$ & & Pe. & Cha. & SA & $\mathrm{A}, \mathrm{B}$ & Hel dig \\
\hline Trichodesmaafricanum (L.) R. Br. & & Pe. & Cha. & SA and SZ & $\mathrm{A}, \mathrm{B}$ & Triafr \\
\hline Anastaticahierochuntica L. & \multirow{8}{*}{ Brassicaceae } & An. & The. & SA & $\mathrm{A}, \mathrm{B}$ & Ana hie \\
\hline Brassica tournefortii Gouan. & & An. & The. & Med, IR, and SA & A & Bra tou \\
\hline Diplotaxis acris (Forssk.) Boiss. & & An. & The. & SA & $\mathrm{A}, \mathrm{B}$ & Dip acr \\
\hline Diplotaxis harra (Forssk.) Boiss. & & Pe. & Hem. & Med and SA & $\mathrm{A}, \mathrm{B}$ & Dip har \\
\hline Eruca sativa Mill. & & An. & The. & $\begin{array}{c}\text { Med, IR, R, and } \\
\text { SA }\end{array}$ & B & Eru sat \\
\hline Farsetia aegyptia Turra. & & Pe. & Cha. & SA and SZ & $\mathrm{A}, \mathrm{B}$ & Far aeg \\
\hline Matthiola longipetala (Vent.) DC. & & An. & The. & Med and IR & A & Mat lon \\
\hline Zilla spinosa (L.) Prant. & & Pe. & Cha. & SA & $\mathrm{A}, \mathrm{B}$ & Zil spi \\
\hline Cleome droserifolia (Forssk.) Delile & Capparaceae & Pe. & Cha. & SA and IR & $\mathrm{A}, \mathrm{B}$ & Cle dro \\
\hline Gymnocarpos decandrus Forssk. & \multirow{6}{*}{ Caryophyllaceae } & Pe. & Cha. & SA & $\mathrm{A}, \mathrm{B}$ & Gym dec \\
\hline Gypsophila capillaris (Forssk.) C. Chr. & & Pe. & Hem. & SA and IR & $\mathrm{A}, \mathrm{B}$ & Gyp cap \\
\hline Herniaria hemistemon J. Gay & & Pe. & Hem. & Med and SA & A & Her hem \\
\hline Polycarpaea repens (Forssk.) Asch. & & Pe. & Cha. & SA & A & Pol rep \\
\hline Silene viviani Steud. & & An. & The. & Med and SA & $\mathrm{A}$ & Sil viv \\
\hline Sphaerocoma hookeri T. Anderson & & Pe. & Cha. & SA & A & Sph hoo \\
\hline Anabasis setifera Moq. & \multirow{5}{*}{ Chenopodiaceae } & Pe. & Cha. & SA & B & Ana Moq \\
\hline Bassia indica (Wight) Scott. & & An. & The. & IR and SZ & $\mathrm{A}$ & Bas ind \\
\hline Bassia muricata (L.) Asch. & & An. & The. & IR and SA & A & Bas mur \\
\hline Chenopodium murale L. & & An. & The. & COSM & $\mathrm{A}, \mathrm{B}$ & Che mur \\
\hline Haloxylonsalicornicum (Moq.) Bunge & & Pe. & Cha. & SA & $\mathrm{A}, \mathrm{B}$ & Hal sal \\
\hline Helianthemum lippi (L.) Dum. Cours. & Cistaceae & Pe. & Cha. & SA and SZ & A & Hel lip \\
\hline $\begin{array}{c}\text { Cleome amblyocarpa Barratte and } \\
\text { Murb. }\end{array}$ & Cleomaceae & An. & The. & IR and SA & A & Cle amb \\
\hline Convolvulus hystrix Vahl & Convolvulaceae & Pe. & Cha. & SA and SZ & B & Con hys \\
\hline Citrullus colocynthis (L.) Schrad. & Cucurbitaceae & Pe. & Hem. & SA & B & Cit col \\
\hline Ephedra alata Decne. & Ephedraceae & Pe. & Cha. & SA & B & Ephala \\
\hline $\begin{array}{c}\text { Chrozophora plicata (Vahl) A. Juss. ex } \\
\text { Spreng. }\end{array}$ & \multirow{5}{*}{ Euphorbiaceae } & An. & The. & $\mathrm{SZ}$ & B & Chr pli \\
\hline Euphorbia peplus L. & & An. & The. & Med, IR, and ER & $\mathrm{A}, \mathrm{B}$ & Eup pep \\
\hline Euphorbia prostrata Aiton & & An. & The. & PAN & A & Eup pro \\
\hline Euphorbia retusa Forssk. & & Pe. & Hem. & SA & $\mathrm{A}, \mathrm{B}$ & Eup ret \\
\hline Euphorbia exigua L. & & An. & The. & Med and IR & B & Eup \\
\hline
\end{tabular}


Table 2. Cont.

\begin{tabular}{|c|c|c|c|c|c|c|}
\hline Species & Family & Life Span & Life Form & $\begin{array}{l}\text { Floristic } \\
\text { Category }\end{array}$ & Record & Abbreviation \\
\hline Acacia tortilis (Forssk.) Hayne & \multirow{8}{*}{ Fabaceae } & Pe. & Pha. & SA and SZ & $\mathrm{A}, \mathrm{B}$ & Aca tor \\
\hline Astraglus spinosus (Forssk.) Muschl. & & Pe. & Cha. & Med, IR, and SA & A & Ast spi \\
\hline Crotalaria aegyptiaca Benth. & & Pe. & Cha. & SA & $\mathrm{A}, \mathrm{B}$ & Cro aeg \\
\hline Lotus glinoides Delile & & An. & The. & $\mathrm{SZ}$ & A & Lot gli \\
\hline Melilotus indicus (L.) All. & & An. & The. & Med, IR, and SA & A & Mel ind \\
\hline $\begin{array}{l}\text { Retama raetam (Forssk.) Webb and } \\
\text { Berthel. }\end{array}$ & & Pe. & Pha. & SA & $\mathrm{A}, \mathrm{B}$ & Ret rae \\
\hline Senna alexandrina Mill. & & Pe. & Cha. & SA and SZ & A & Sen ale \\
\hline Trigonella stellata Forssk. & & An. & The. & SA and IR & $\mathrm{A}, \mathrm{B}$ & Triste \\
\hline Erodium crassifolium L'Her. & \multirow{4}{*}{ Geraniaceae } & Pe. & Hem. & SA & B & Ero cra \\
\hline Erodium glaucophyllum (L.) L'Hér. & & Pe. & Hem. & SA & B & Erogla \\
\hline $\begin{array}{l}\text { Erodium laciniatum (Cav.) Wild. } \\
\text { subsp. Laciniatum }\end{array}$ & & An. & The. & Med & $\mathrm{A}, \mathrm{B}$ & Ero lac \\
\hline $\begin{array}{l}\text { Erodium laciniatum (Cav.) Wild. } \\
\text { subsp. Pulverulentum }\end{array}$ & & An. & The. & Med & $\mathrm{A}, \mathrm{B}$ & Ero lac \\
\hline Lavandula coronopifolia Poir. & \multirow{3}{*}{ Lamiaceae } & Pe. & Cha. & SA & $\mathrm{A}, \mathrm{B}$ & Lav cor \\
\hline Salvia aegyptiaca L. & & Pe. & Cha. & IR and SA & A & Sal aeg \\
\hline Salvia deserti Decne. & & Pe. & Cha. & SA and IR & $\mathrm{A}, \mathrm{B}$ & Sal des \\
\hline Asphodelus fistulosus L. & Liliaceae & An. & The. & Med, IR, and SA & $\mathrm{A}$ & Asp fis \\
\hline Malva parvifolra $\mathrm{L}$. & Malvaceae & An. & The. & Med and IR & $\mathrm{A}, \mathrm{B}$ & Mal par \\
\hline Neurada procumbens L. & Neuradaceae & An. & The. & IR and SA & $\mathrm{A}$ & Neu pro \\
\hline Nitraria retusa (Forssk.) Asch. & Nitrariaceae & Pe. & Pha. & SA & B & Nit ret \\
\hline Orobanche crenata Forssk. & Orobanchaceae & An. & Parasite & Med and IR & B & Oro cre \\
\hline Medicago laciniata (L.) Mill. & Fabaceae & An. & The. & SA & $\mathrm{B}$ & $\operatorname{Med}(L$ \\
\hline Plantago ovata Forssk. & Plantaginaceae & An. & The. & Med, IR, and SA & $\mathrm{A}, \mathrm{B}$ & Pla ova \\
\hline Avena fatua $\mathrm{L}$. & \multirow{11}{*}{ Poaceae } & An. & The. & PAL & A & Ave fat \\
\hline Imperata cylindrica (L.) Raeusch & & Pe. & Hem. & Med, IR, and SA & $\mathrm{A}, \mathrm{B}$ & $\operatorname{Imp} c y l$ \\
\hline Lasiurus scindicus Henrard. & & Pe. & Hem. & SA and SZ & A & Las sci \\
\hline Lolium multiflorum Lam. & & An. & The. & Med, IR, and ER & A & Lol mul \\
\hline Panicum turgidum Forssk. & & Pe. & Hem. & SA & $\mathrm{A}, \mathrm{B}$ & Pan tur \\
\hline $\begin{array}{l}\text { Pennisetum divisum Forssk. Ex J. F. } \\
\text { Gmel }\end{array}$ & & Pe. & Hem. & SA & A & Pen div \\
\hline Phalaris minor Retz. & & An. & The. & Med and IR & A & Pha min \\
\hline $\begin{array}{c}\text { Phragmites australis (Cav.) Trin. ex } \\
\text { Steud. }\end{array}$ & & Pe. & Geophyte & COSM & $\mathrm{A}, \mathrm{B}$ & Phr aus \\
\hline Poa annua L. & & An. & The. & COSM & A & Poa ann \\
\hline Schismus barbatus (L.) Thell. & & An. & The. & Med, IR, and SA & A & Sch bar \\
\hline Trisetaria linearis Forssk. & & An. & The. & Med and IR & A & Trilin \\
\hline
\end{tabular}


Table 2. Cont.

\begin{tabular}{|c|c|c|c|c|c|c|}
\hline Species & Family & Life Span & Life Form & $\begin{array}{l}\text { Floristic } \\
\text { Category }\end{array}$ & Record & Abbreviation \\
\hline Emex spinosa (L.) Campd. & Polygonaceae & An. & The. & Med and SA & $\mathrm{A}$ & Eme spi \\
\hline Rumex vesicarius L. & Polygonaceae & An. & The. & Med, SA, and SZ & $\mathrm{A}, \mathrm{B}$ & Rum ves \\
\hline $\begin{array}{c}\text { Caylusea hexagyna (Forssk.) M. L. } \\
\text { Green }\end{array}$ & \multirow{3}{*}{ Resedaceae } & An. & The. & SA and SZ & $\mathrm{A}$ & Cay hex \\
\hline Ochradenus baccatus Delile. & & Pe. & Pha. & SA & $\mathrm{A}, \mathrm{B}$ & Och bac \\
\hline Reseda decursiva Forssk. & & An. & The. & SA & $\mathrm{A}, \mathrm{B}$ & Res dec \\
\hline $\begin{array}{c}\text { Haplophyllum tuberculatum (Forssk.) } \\
\text { A. Juss. }\end{array}$ & Rutaceae & Pe. & Hem. & SA & $\mathrm{A}, \mathrm{B}$ & Hap tub \\
\hline Kickxia aegyptiaca (L.) Nabelek & \multirow{2}{*}{ Scrophulariaceae } & Pe. & Cha. & Med and SA & $\mathrm{A}, \mathrm{B}$ & Kic aeg \\
\hline Scrophularia deserti Delile & & Pe. & Cha. & SA & $\mathrm{A}, \mathrm{B}$ & Scr des \\
\hline Hyoscyamus muticus L. & \multirow{3}{*}{ Solanaceae } & Pe. & Cha. & IR and SA & $\mathrm{A}$ & Hyo mut \\
\hline Lycium shawii Roem. and Schult. & & Pe. & Pha. & SA and SZ & $\mathrm{A}, \mathrm{B}$ & Lyc sha \\
\hline Solanum nigrum L. & & An. & The. & COSM & B & Sol nig \\
\hline Reaumuria hirtella Jaub. and Spach. & \multirow{3}{*}{ Tamaricaceae } & Pe. & Cha. & IR and SA & $\mathrm{A}, \mathrm{B}$ & Rea hir \\
\hline Tamarix aphylla (L.) H. Karst. & & Pe. & Cha. & $\mathrm{SA}, \mathrm{IR}$, and SZ & $\mathrm{A}, \mathrm{B}$ & Tam aph \\
\hline Tamarix nilotica(Ehrenb.) Bunge & & Pe. & Pha. & SA and SZ & $\mathrm{A}, \mathrm{B}$ & Tam nil \\
\hline Forsskaolea tenacissima $\mathrm{L}$. & Urticaceae & Pe. & Hem. & SA and SZ & A & For ten \\
\hline Verbena officinalis L. & Verbenaceae & Pe. & Hem. & Med and SA & A & Ver off \\
\hline Fagonia arabica L. & \multirow{5}{*}{ Zygophyllaceae } & Pe. & Cha. & SA & $\mathrm{A}, \mathrm{B}$ & Fag ara \\
\hline Fagonia mollis Delile & & Pe. & Cha. & SA & $\mathrm{A}, \mathrm{B}$ & Fag mol \\
\hline Zygophyllumcoccineum L. & & Pe. & Cha. & SA and SZ & $\mathrm{A}, \mathrm{B}$ & Zyg coc \\
\hline Zygophyllumdecumbens Delile & & Pe. & Cha. & SA & $\mathrm{A}, \mathrm{B}$ & Zyg dec \\
\hline Zygophyllum simplex L. & & An. & The. & PAL & $\mathrm{A}, \mathrm{B}$ & Zyg sim \\
\hline
\end{tabular}

An. = Annual, Bi. = Biennial, Pe. = Perennial, The. = Therophyte, Hem. = Hemicryptophyte, Cha. $=$ Chamaephyte, Pha. $=$ Phanerophyte, $\mathrm{SA}=$ Saharo-Sindian, Med = Mediterranean, $\mathrm{SZ}=$ Sudano-Zambesian, $\mathrm{IR}=$ Irano-Turanian, $\mathrm{ER}=$ Euro-Siberian, $\mathrm{A}=$ a species recorded only by Abdelaal [60], $\mathrm{B}=$ a species recorded only in the current study, and A, B = a species shared between the current study and Abdelaal [60].

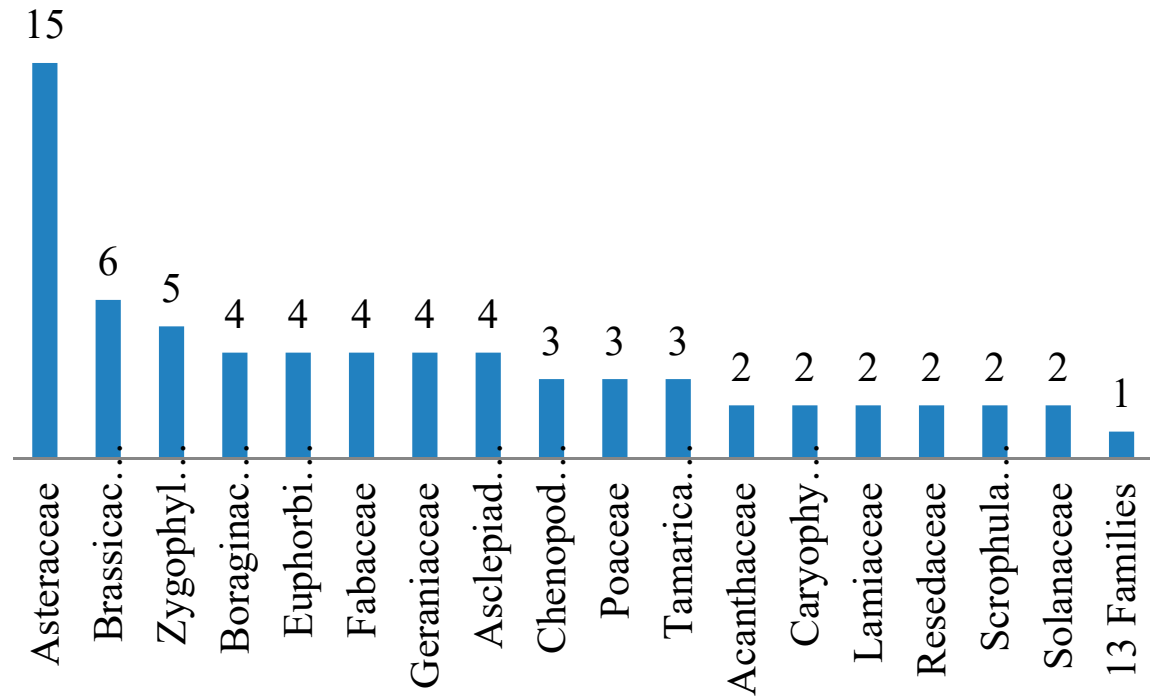

Figure 3. Number of species distributed across different families recorded in Wadi Hagul. 
Regarding the life span of the listed species, most of them are perennials (54 species, $67.5 \%$ ), followed by annuals ( 25 species, $31.3 \%$ ). A single biennial species was Centaurea aegyptiaca (Table 2 and Figure 4). Comparing species according to their life form, we found approximately $40 \%$ chamaephytes, $31 \%$ therophytes, $15 \%$ hemicryptophytes, and $11 \%$ phanerophytes. Parasite and geophyte species were represented by a single species each (Table 2 and Figure 5).

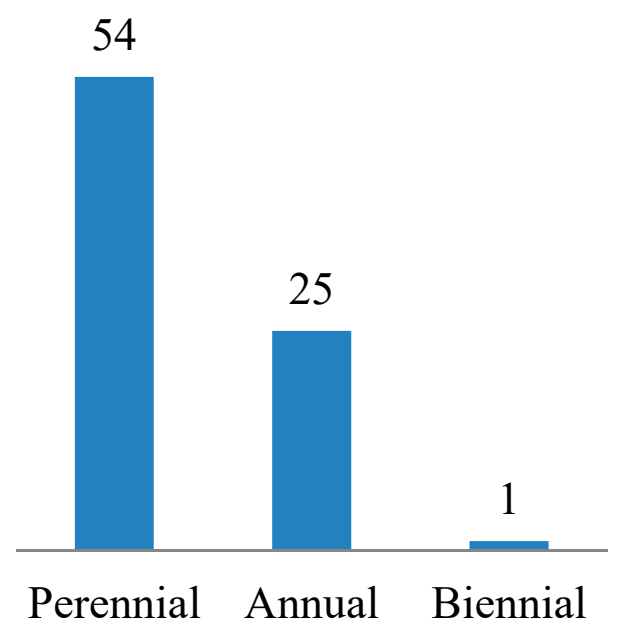

Figure 4. Life span of the species recorded in Wadi Hagul.

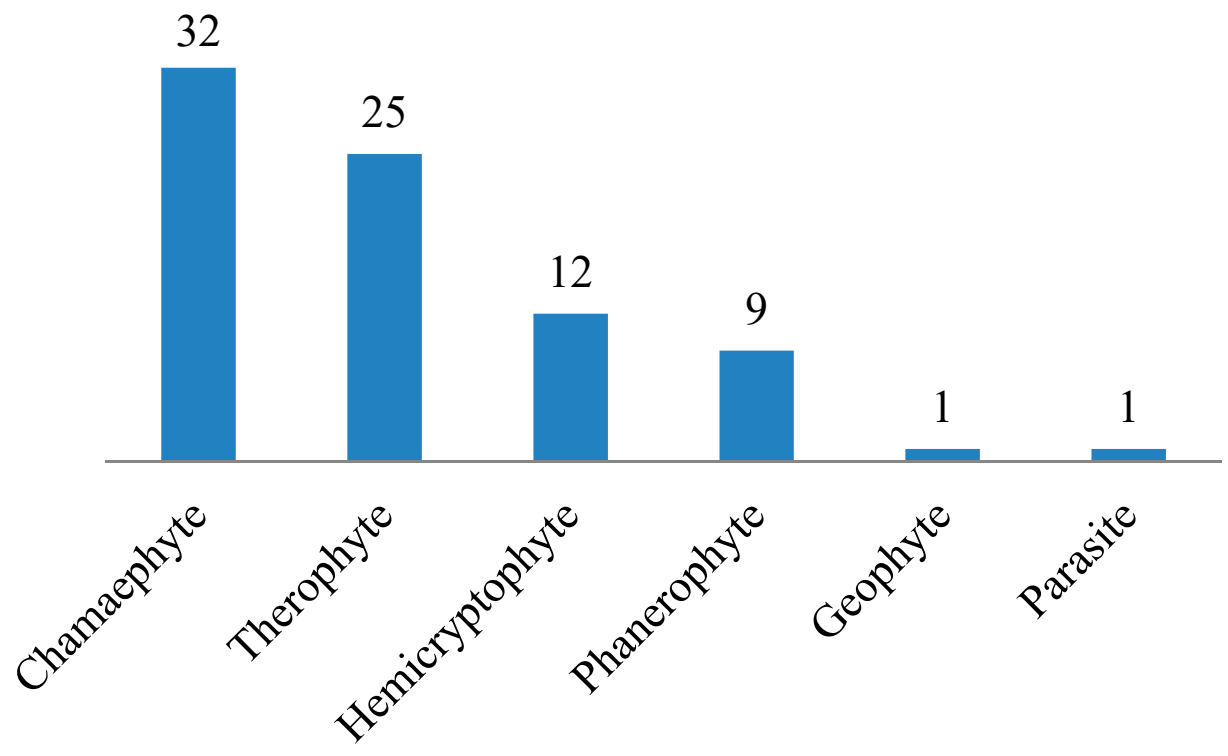

Figure 5. Life forms of species recorded in Wadi Hagul.

With respect to a phytogeographical region, monoregional geoelements were the most common floristic category ( 40 species, $50 \%$ ), followed by biregionals (27 species, $33.8 \%$ ), and pleuriregionals (8 species, $10 \%$ ). Cosmopolitan and palaeotropical species were represented by one and one species, respectively (Table 2 and Figure 6). 


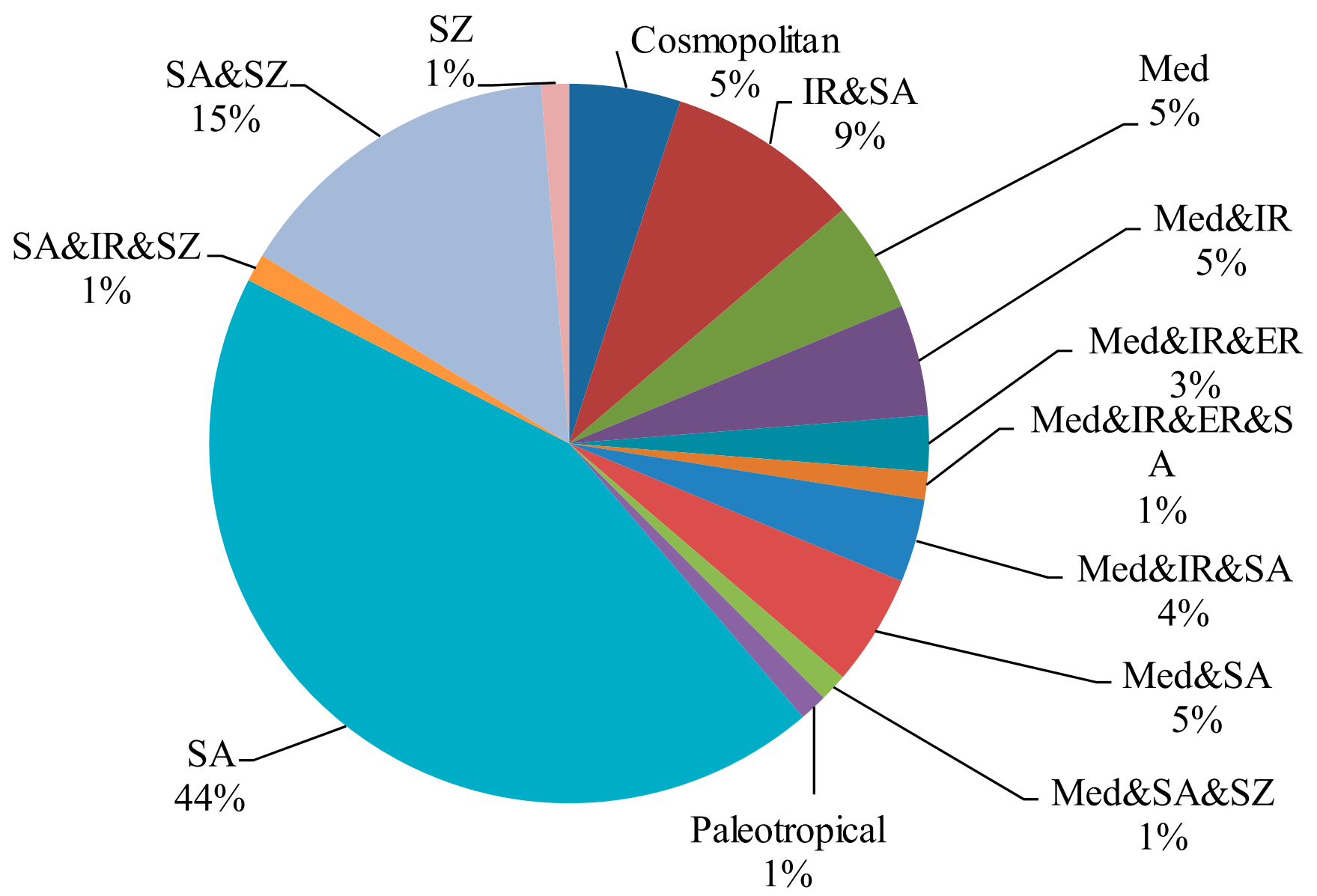

Figure 6. Chorotypes of the species recorded in Wadi Hagul.

In the current study, 80 taxa were recorded, whereas Abdelaal [60] listed 98 taxa. The number of species recorded in this study was 19 (not recorded in the previous study), whereas 38 species were recorded by Abdelaal [60]. A total of 61 plant species were shared between the two studies (Table 2).

The averages of species richness, evenness, and Shannon's and Simpson's indices were $3,0.556,0.722$, and 0.3755 , respectively. Hill's number when $Q=$ zero, gamma, alpha and beta diversity were 63, 9.7 and 6.5, respectively. Hill's number when $Q=$ one, gamma, alpha and beta diversity were 8.2, 4.3 and 1.9, respectively. Hill's number when $Q=$ two, gamma, alpha and beta diversity were $5,3.3$ and 1.5 , respectively.

\subsection{Soil Characteristics}

Soil samples were taken at a depth of 0 to $30 \mathrm{~cm}$ in the studied localities, and 15 soil factors were analyzed. Soil pH, TDS, and EC values ranged 7.4 to 8.5, 82 to $9840 \mathrm{ppm}$, and 0.128 to $15.375 \mathrm{dS} / \mathrm{m}$, respectively. Calcium, magnesium, sodium, and potassium contents ranged 0.7 to $49 \mathrm{meq} / \mathrm{L}, 0.22$ to $28 \mathrm{meq} / \mathrm{L}, 0.21$ to $63 \mathrm{meq} / \mathrm{L}$, and 0.104 to $11.2 \mathrm{meq} / \mathrm{L}$, respectively. Carbonate, bicarbonate, chloride, and sulfate contents ranged between 0.15 and $0.45 \%, 0.305$ and $0.61 \%, 0.5$ and $43 \mathrm{meq} / \mathrm{L}$, and 1.2 to $76 \mathrm{meq} / \mathrm{L}$, respectively. Organic carbon, clay, and silt contents in all soil samples were less than $1.4 \%, 5 \%$, and 15\%, respectively. In addition, sand contribution in all soil samples was more than $81 \%$ (Table 3 ). 
Table 3. Descriptive statistical analysis of soil factors.

\begin{tabular}{|c|c|c|c|c|c|}
\hline Soil Factor & $\begin{array}{c}\text { Mean } \pm \text { Standard } \\
\text { Error }\end{array}$ & Range (Max-Min) & $\begin{array}{l}\text { Standard } \\
\text { Deviation }\end{array}$ & Median & $\begin{array}{l}\text { Interquartile } \\
\text { Range (IQR) }\end{array}$ \\
\hline $\mathrm{pH}$ & $8 \pm 0.0736$ & $1.1(8.5-7.4)$ & 0.329 & 8.1 & 0.55 \\
\hline T.D.S. (ppm) & $1077.65 \pm 508.726$ & $9,758(9840-82)$ & $2,275.094$ & 360.5 & 533 \\
\hline E.C. $(\mathrm{dS} / \mathrm{m})$ & $1.684 \pm 0.795$ & $15.247(15.375-0.128)$ & 3.555 & 0.563 & 0.832 \\
\hline $\mathrm{Ca}^{+2}(\mathrm{meq} / \mathrm{L})$ & $6.353 \pm 2.537$ & $48.3(49-0.7)$ & 11.346 & 2.65 & 2.952 \\
\hline $\mathrm{Mg}^{+2}$ (meq/L) & $3.053 \pm 1.366$ & $27.78(28-0.22)$ & 6.108 & 1.27 & 1.37 \\
\hline $\mathrm{Na}^{+}($meq/L) & $6.025 \pm 3.421$ & $62.79(63-0.21)$ & 15.301 & 1.15 & 2.205 \\
\hline $\mathrm{K}^{+}(\mathrm{meq} / \mathrm{L})$ & $1.18 \pm 0.565$ & $11.096(11.2-0.104)$ & 2.528 & 0.165 & 1.288 \\
\hline $\mathrm{CO}_{3}^{-2}(\%)$ & $0.225 \pm 0.0231$ & $0.3(0.45-0.15)$ & 0.103 & 0.15 & 0.15 \\
\hline $\mathrm{HCO}_{3}{ }^{-}(\%)$ & $0.32 \pm 0.0153$ & $0.305(0.61-0.305)$ & 0.0682 & 0.305 & 0 \\
\hline $\mathrm{Cl}^{-}(\mathrm{meq} / \mathrm{L})$ & $4.532 \pm 2.278$ & $42.5(43-0.5)$ & 10.189 & 1.235 & 1.37 \\
\hline $\mathrm{SO}_{4}^{-2}(\mathrm{meq} / \mathrm{L})$ & $9.57 \pm 3.961$ & $74.8(76-1.2)$ & 17.714 & 3.9 & 4.75 \\
\hline Organic carbon (\%) & $0.888 \pm 0.079$ & $1.2(1.32-0.12)$ & 0.353 & 0.84 & 0.66 \\
\hline Sand $(\%)$ & $83.333 \pm 0.19$ & 3.05 (84.7-81.65) & 0.851 & 83.4 & 1.428 \\
\hline Silt (\%) & $13.31 \pm 0.137$ & $1.9(14.3-12.4)$ & 0.613 & 13.4 & 1.15 \\
\hline Clay (\%) & $3.357 \pm 0.165$ & $2.64(4.7-2.06)$ & 0.739 & 3.325 & 1.087 \\
\hline
\end{tabular}

$\mathrm{pH}=$ soil reaction, T.D.S. $=$ total dissolved salts, E.C. $=$ electrical conductivity, $\mathrm{Ca}^{2+}=$ calcium, $\mathrm{Mg}^{2+}=$ magnesium, $\mathrm{Na}^{+}=$sodium, $\mathrm{K}^{+}=$potassium, $\mathrm{CO}_{3}{ }^{2-}=$ carbonates, $\mathrm{HCO}_{3}{ }^{-}=$bicarbonates, $\mathrm{Cl}^{-}=$chlorides, $\mathrm{SO}_{4}{ }^{2-}=$ sulfates, ppm $=$ parts per million, $\mathrm{dS} / \mathrm{m}=$ deciSiemens per meter and $\mathrm{meq} / \mathrm{L}=$ milliequivalents per liter.

\subsection{Effect of Environmental Factors on the Distribution of Plant Communities in the Studied Localities}

The distribution of the studied localities and recorded plant species and their relationships to environmental factors are illustrated in Figure 7. DCCA showed that altitude, latitude, organic carbon content, Tamarix aphylla, Gymnocarpos decandrus, Fagonia Arabica, Reaumuria hirtella, and Erodium laciniatum positively correlated with axis 1. Longitude, $\mathrm{Mg}^{2+}$, clay content, Citrullus colocynthis, Chrozophora plicata, Aerva javanica, and Orobanche crenata are negatively correlated with axis 1 . Sand content, $\mathrm{pH}$, Reseda decursiva, Scrophularia deserti, Rumex vesicarius, Conyza aegyptiaca, Diplotaxis acris, Diplotaxis harra, Haplophyllum tuberculatum, Trichodesma africanum, Sonchus oleraceus, Conyza bonariensis, Euphorbia retusa, Gypsophila capillaris, Chenopodium murale, and Kickxia aegyptiaca positively correlated with axis 2, whereas T.D.S., E.C., $\mathrm{Cl}^{-}, \mathrm{Ca}^{2+}, \mathrm{K}^{+}, \mathrm{Na}^{+}, \mathrm{SO}_{4}{ }^{2-}, \mathrm{CO}_{3}{ }^{-}, \mathrm{HCO}_{3}{ }^{2-}$, Pulicaria undulata, Calotropis procera, Phragmites australis, and Imperata cylindrica negatively correlated with axis 2. 


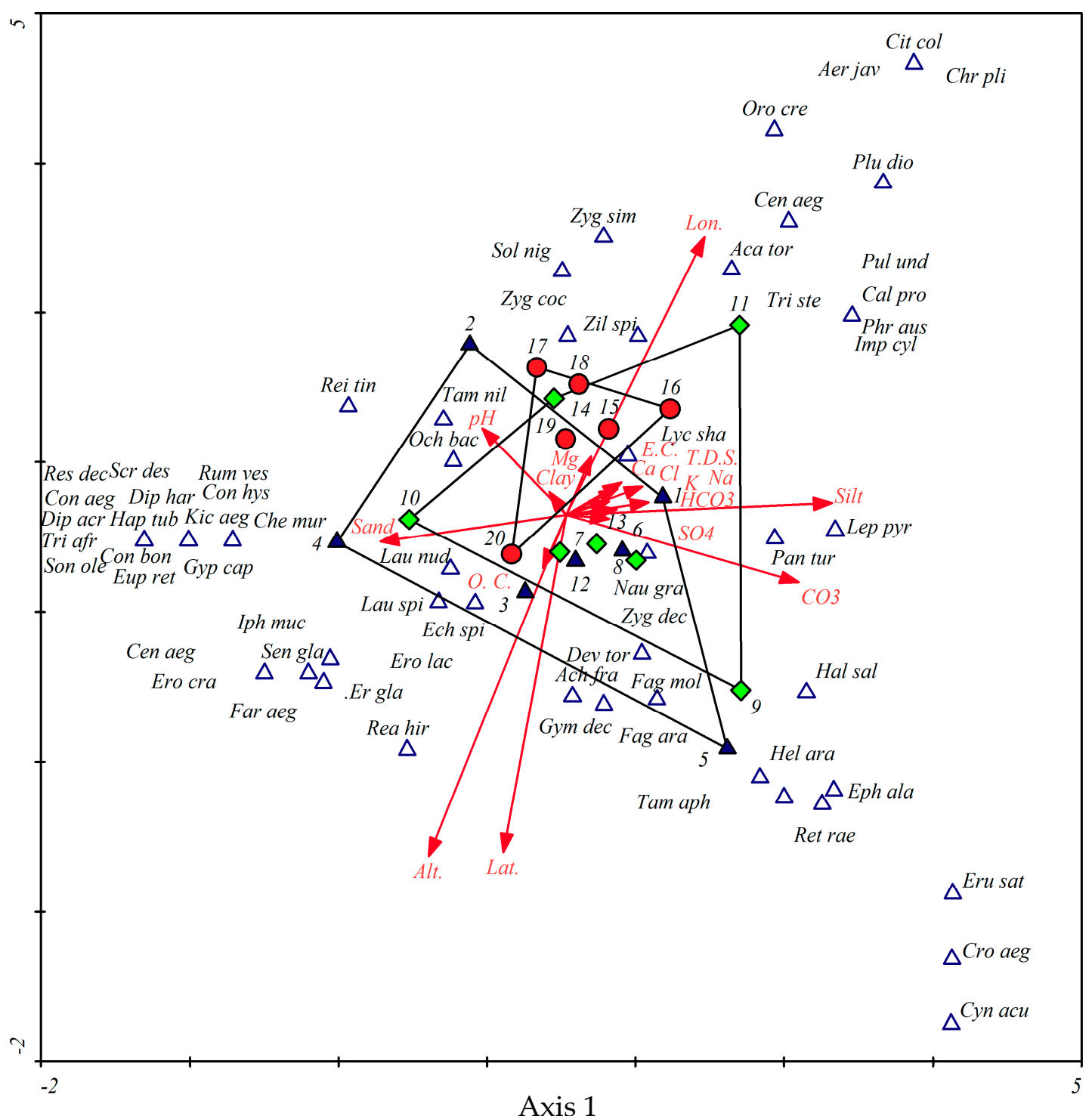

\section{SPECIES}

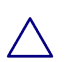

ENV. VARIABLES

\section{SAMPLES}

\section{$\Delta-$ Class $1 \diamond-$ Class $2 \bigcirc-$ Class 3}

Axis 2

Figure 7. DCCA triplot showing the distribution of the studied localities and the recorded plant species as well as their relationships to environmental factors. The triangles represent species, and the arrows represent environmental variables. Arrow length expresses relative importance of an environmental variable. Dropping perpendicular to the arrows from each of the "species" indicates the species' relative position along the ecological gradient represented by an arrow. 


\subsection{Vegetation Change}

SAVI for 2013 ranged from -0.02 to 0.42 ; for 2015 , it ranged from -0.011 to 0.32 ; and for 2020 , it ranged from -0.18 to 0.28 (Figure 8 ).
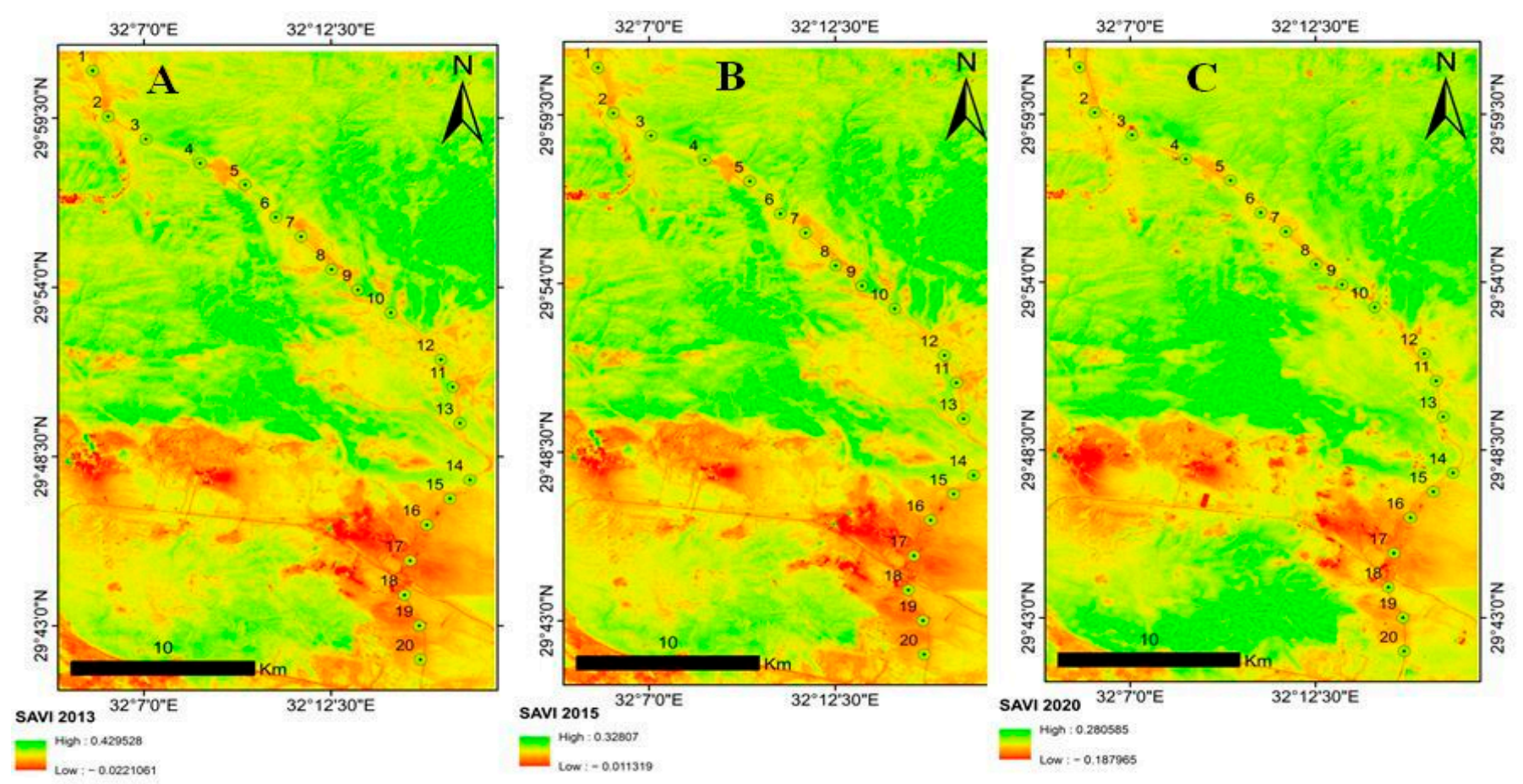

Figure 8. SAVI maps for 2013 (A), 2015 (B), and 2020 (C).

\section{Discussion}

In Wadi Hagul, 80 plant species belonging to 30 families were recorded. Among them, Asteraceae, Brassicaceae, and Zygophyllaceae were the most frequent families. These results are very similar to those reported in 2009 by Zahran and Willis [44] (31 species recorded) and in 2000 by Marie [61] (37 species recorded), who found that Asteraceae and Zygophyllaceae were the most common plant families in Wadi Hagul. By contrast, in 2016, Abdelaal [60] recorded 98 species, where Asteraceae and Poaceae were the most frequent families. Eight families (Aizoaceae, Cistaceae, Cleomaceae, Liliaceae, Neuradaceae, Polygonaceae, Urticaceae and Verbenaceae), each represented by only one plant species, were recorded in Abdelaal [60], and none of them were recorded in this study. Asteraceae were reported as the most common family in other Eastern desert wadies (Wadi Asyouti and Wadi Habib) [62]. Asteraceae was known for having a proportion of salt-tolerant and xerophytic species [63]. Asteraceae makes up the bulk of floristic composition in Egypt. It is represented by 98 genera, and 234 species [48,64]. Mashaly [65] reported a list of 62 species, with no alien species found.

The perennial plant group was most represented (67.5\%) in the current study; this is consistent with the results of Zahran and Willis [44], Marie [61], and Abdelaal [60], who studied vegetation in the same study area during previous years. Regarding the number of annual species in Wadi Hagul, it has changed over the years of the study. This may be due to variation in the total rainfall during the studied years.

Life forms of species depend mainly on adaptation to the environment, particularly climate [66-69]. Life forms of desert plants are closely related to precipitation [70,71] and are correlated with both landform and topography [72-74]. In the present study, the chamaephyte life form was most represented (40\%). Therophyte was the second most common life form (31.3\%). These results are in accordance with the results of Abd ElGalil [75], who studied the floristic composition of Wadi Al-Assiuty, Eastern Desert, Egypt. 
In arid and semi-arid regions, chamaephyte and therophyte were found to be the most common life-forms [76-78].

Saharo-Arabian species captured the highest percentage in the floristic categories (43.75\%). This result is concordant with Zahran and Willis [44], Marie [61], and Abdelaal [60]. It is worth noting that Saharo-Arabian species are good indicators for desert environmental conditions [79-81].

Species richness, which refers to the number of various plant species in the stands, is one of the most important indices of species diversity. In the studied stands, the average of species richness recorded three species, which is a low number. This could be due to a variety of factors, including the severe environment and climate that characterize the study area, which may be an obstacle to the growth of some plant species. Species evenness is a description of the distribution of species abundance in a community. The average of species evenness was 0.7. Species evenness is measured on a scale of 0 to 1 , with 0 representing the lowest evenness (one species has 100\% coverage) and 1 representing the highest evenness (coverage is evenly spread among a number of species). This may be due to the presence of a very dominant species in a community causes the less competitive species to be suppressed [82]. Shannon index depends strongly on species richness [83]. Simpson index is not a very intuitive measure of diversity since higher values indicate lower diversity [84].

The results of DCCA analysis indicated that latitude, longitude, altitude, silt and sand contents, $\mathrm{pH}$, and $\mathrm{CO}_{3}{ }^{2-}$ content are the most important factors affecting the distribution of vegetation in Wadi Hagul. These results are somewhat consistent with those of Mashaly [62], who stated that the most influential soil factors for the distribution of vegetation in Wadi Hagul are soil texture, $\mathrm{Na}^{+}, \mathrm{pH}$, and organic matter. Abdelaal [60] mentioned that $\mathrm{K}^{+}, \mathrm{Na}^{+}$, organic matter, moisture content, $\mathrm{pH}$, E.C., and $\mathrm{Cl}^{-}$were the most affecting soil parameters for the distribution of vegetation in Wadi Hagul. Plant species associated with the increase in the proportion of sand in the soil and soil $\mathrm{pH}$ were Tamarix nilotica, Ochradenus baccatus, Launea nudicalus, Launea nudicalus and Rumex vesicarius. The longitude and the amount of $\mathrm{Mg}^{2+}$ in the soil were the most important factors associated with many plant species such as; Zilla spinosa, Zygophyllum simplex and Zygophyllum coccineum. Most of the salinity factors (E.C., T.D.S., $\mathrm{Ca}^{2+}, \mathrm{Cl}^{-}, \mathrm{Na}^{+}$and $\left.\mathrm{K}^{+}\right), \mathrm{CO}_{3}{ }^{2-}, \mathrm{HCO}_{3}{ }^{-}$ and the percentage of silt in soil were associated with some species such as; Lycium shawii, Leptadenia pyrotechnica, Panicum turgidum and Haloxylon salicornicum. Latitude, altitude and the amount of organic carbon in soil were important factors in the distribution of some plant species such as Echinops spinosus, Erodium laciniatum, Erodium glaucophyllum and Reaumuria hirtella.

Many of the threatened plant species recorded in previous studies were not recorded in this study, including Aizoon canariensis, Artemisia judaica, Ifloga spicata, Silene viviani, Sphaerocoma hookeri, Helianthemum lippi, Astraglus spinosus, Senna alexandrina, Salvia aegyptiaca, Schismus barbatus, Hyoscyamus muticus, and Verbena officinalis. As a result, action must be taken to safeguard threatened species by a variety of measures, including the establishment of protected areas, criminalizing exposure to endangered plants, creating a gene bank for these plants, and attempting to increase their numbers in practice.

In this study, many alien and invasive species, such as Euphorbia prostrate, were recorded [85]. The introduction of invasive and alien species into natural habitats represents a threat to existing species. Assaeed et al. [86] indicated that invasive and exotic plants may pose a threat to natural resources and biodiversity, especially in arid habitats. Successful invaders often exhibit great degrees of adaptability, allowing them to thrive in a variety of environments $[87,88]$. Plant shoot and root system features are thought to be good morphological criteria for predicting successful invasion in many habitat types [89]. Many invasive species contain allelopathic chemicals that enable them to invade and control plant communities [90].

Climate changes, in addition to human encroachments such as the construction of roads and the establishment of new cities, pose the main pressure on vegetation. Climate 
changes and human impact negatively affect biodiversity in several Wadies in the Egyptian Eastern Desert [91].

In this study, SAVI decreased during 2013 (from -0.02 to 0.42 ), 2015 (from -0.011 to 0.32 ), and 2020 (from -0.18 to 0.28 ). This result could be due to various human impacts in Wadi Hagul such as the construction of the new road Al-Galala-Hagul-Zafarana, which is $84 \mathrm{~km}$ long and $24 \mathrm{~m}$ wide and crosses Wadi Hagul, in addition to many other threats such as overgrazing, plant collection, and increasing demand for energy, which have led to exploration for oil and natural gas near Wadi Hagul. Large population growth in recent times has also led to increasing demand for building materials and opening quarries inside Wadi Hagul, which resulted in a local increase in transport and pollution. Finally, it was discovered that if environmental conditions (such as human interventions and climate changes) alter and become unsuitable for plant growth, they have a negative impact on vegetation cover, thus lowering the SAVI values.

In recent times, the preservation and protection of wildlife have become an urgent necessity, especially in the light of misuse of natural resources and encroachment of wildlife. Economic development and wildlife conservation can be simultaneously achieved by following the principles, rules, and requirements of sustainable development for balanced usage of available resources.

\section{Conclusions}

This study was conducted in an unprotected area, Wadi Hagul, Eastern desert, Egypt, to evaluate the relationship between environmental factors and the distribution of plant species, as well as evaluate the negative effects of uncontrolled human activities on both floristic composition and vegetation structure. Climate change, reflected in high temperatures and a lack of rain, also has a negative impact on vegetation cover in the study area, which is classified as a semi-arid desert. Ecosystems in general, especially deserts, are greatly affected by irresponsible human interventions. Hence, plans and strategies should be developed to conserve biodiversity. Within this context, the outcomes of this study, as well as those of other similar studies, will aid in the implementation of necessary environmental protection measures. Our study clearly showed a decreasing trend of SAVI across Wadi Hagul during 2013, 2015, and 2020. Physical factors, rather than anthropogenic, were the primary driving force for vegetation dynamics, whereas the effects of anthropogenic factors may be magnified when physical environmental factors provide unsuitable ambiance for vegetation growth. Other indexes must be measured to estimate vegetation cover, especially in unprotected areas subject to major human interventions, as can be carried out in future studies.

Supplementary Materials: The following are available online at https:/ /www.mdpi.com/article/10 .3390/plants10091906/s1, Figure S1: Climate diagram of Wadi Hagul (1990-2020): mean maximum temperature $\left({ }^{\circ} \mathrm{C}\right)$, mean minimum temperature $\left({ }^{\circ} \mathrm{C}\right)$, precipitation $(\mathrm{mm})$, hot days $\left({ }^{\circ} \mathrm{C}\right)$, and cold nights, Figure S2: Wind direction and velocity in Wadi Hagul (1990-2020).

Author Contributions: Conceptualization, A.A.I., R.B. and S.R.; software, R.B. and A.A.I.; validation, A.A.I., S.A. and A.A.A.; formal analysis, R.B., A.A.I., S.A., A.A.A. investigation, A.A.I., R.B. and S.R.; resources, A.A.I., S.R. and R.B.; data curation, A.A.I., S.R. and R.B.; writing-original draft preparation, R.B., A.A.I., S.R.; writing-review and editing, A.A.I., R.B. and S.R.; visualization, A.A.I., R.B., S.A. and A.A.A. All authors have read and agreed to the published version of the manuscript.

Funding: This research received no external funding.

Institutional Review Board Statement: Not applicable.

Informed Consent Statement: Not applicable.

Data Availability Statement: Relevant data applicable to this research are within the paper.

Acknowledgments: Authors thank Abdo Marei Hamed for his keen help during field trips, Ibrahim A. Mashaly for his keen help in identification of plant samples, Om Mohamed A. Khafagi for her help in paper reviewing and Al-Baraa S. M. El-Saied for his help in statistical analysis. 
Conflicts of Interest: The authors declare no conflict of interest.

\section{References}

1. Millennium Ecosystem Assessment. Ecosystems and Human Well-Being: Desertification Synthesis; World Resources Institute: Washington, DC, USA, 2005.

2. Referowska-Chodak, E. Pressures and threats to nature related to human activities in European urban and suburban forests. Forests 2019, 10, 765. [CrossRef]

3. Newton, A.C.; Cayuela, C.; Echeverría, C.; Armesto, J.J.; Del Castillo, R.F.; Golicher, D.; Geneletti, D.; Gonzalez-Espinosa, M.; Huth, A.; López-Barrera, F; et al. Toward integrated analysis of human impacts on forest biodiversity: Lessons from Latin America. Ecol. Soc. 2009, 14, 2. [CrossRef]

4. Kapos, V.; Lysenko, I.; Lesslie, R. Assessing Forest Integrity and Naturalness in Relation to Biodiversity; Forest Resources Assessment Programme, Working Paper 54; Forestry Department FAO: Rome, Italy, 2002.

5. Moustafa, A.A.; Abd El-Wahab, R.H.; Zaghloul, M.S. Conservation and Sustainable Use of Medicinal Plants in Arid and Semi-Arid Ecosystems of Egypt; Final Report; Egyptian Environmental Affairs Agency (EEAA), United Nations Development Programme (UNDP) and Global Environmental Facilities (GEF): Giza, Egypt, 1999.

6. Nakahama, N.; Hirasawa, Y.; Minato, T.; Hasegawa, M.; Isagi, Y.; Shiga, T. Recovery of genetic diversity in threatened plants through use of germinated seeds from herbarium specimens. Plant Ecol. 2015, 216, 1635-1647. [CrossRef]

7. Hussein, E.A.; Abd El-Ghani, M.M.; Hamdy, R.S.; Shalabi, L.F. Do anthropogenic activities affect floristic diversity and vegetation structure more than natural soil properties in hyper-arid desert environments? Diversity 2021, 13, 157. [CrossRef]

8. Sebastian, O.; Sibyll, S.; Wolfgang, L.; Dieter, G. Three centuries of dual pressure from land use and climate change on the biosphere. Environ. Res. Lett. 2015, 10, 044011.

9. Titeux, N.; Henle, K.; Mihoub, J.B.; Regos, A.; Geijzendorffer, I.R.; Cramer, W.; Verburg, P.H.; Brotons, L. Biodiversity scenarios neglect future land-use changes. Glob. Chang. Biol. 2016, 22, 2505-2515. [CrossRef] [PubMed]

10. Pereira, H.M.; Navarro, L.M.; Martins, I.S. Global biodiversity change: The bad, the good, and the unknown. Annu. Rev. Environ. Resour. 2012, 37, 25-50. [CrossRef]

11. Zhu, P.; Cao, W.; Huang, L.; Xiao, T.; Zhai, J. The impacts of human activities on ecosystems within China's nature reserves. Sustainability 2019, 11, 6629. [CrossRef]

12. Wu, J.W.; Miao, C.Y.; Wang, Y.M.; Duan, Q.Y.; Zhang, X.M. Contribution analysis of the long-term changes in seasonal runoff on the Loess Plateau, China, using eight Budyko-based methods. J. Hydrol. 2017, 545, 263-275. [CrossRef]

13. Kong, D.; Miao, C.; Borthwick, A.G.; Lei, X.; Li, H. Spatiotemporal variations in vegetation cover on the Loess Plateau, China, between 1982 and 2013: Possible causes and potential impacts. Environ. Sci. Pollut. Res. 2018, 25, 13633-13644. [CrossRef]

14. Enright, N.J.; Miller, B.P.; Akhter, R. Desert vegetation and vegetation-environment relationships in Kirthar National Park, Sindh, Pakistan. J. Arid Environ. 2005, 61, 397-418. [CrossRef]

15. Abd El-Wahab, R.H. Plant assemblage and diversity variation with human disturbances in coastal habitats of the western Arabian Gulf. J. Arid Land 2016, 8, 787-798. [CrossRef]

16. Kotanska, M.; Buziak-Chmielowiec, E.; Dabrowska, A.; Gladysz, M.; Jakielaszek, A.; Wójcik, T. Human impact on the plant coverof four villages in SE Poland. Steciana 2015, 19, 115-121. [CrossRef]

17. TEEB. The Economics of Ecosystems and Biodiversity: Mainstreaming the Economics of Nature: A Synthesis of the Approach, Conclusions and Recommendations of TEEB; United Nations Environment Programme: Geneva, Switzerland, 2010; Volume 1,47p.

18. Koagne, M.D. Evaluation of Ecological Monitoring System of the Dynamics of Human Activities in the Benue National Park and Its Periphery; Engineer Memory of Water, Forests and Hunting, FASA, Dschang University: Dschang, Cameroon, 2009; 98p.

19. Blicharska, M.; Grandin, U. Why protect biodiversity? Perspectives of conservation professionals in Poland. Int. J. Biodivers. Sci. Ecosyst. Serv. Manag. 2015, 11, 349-362. [CrossRef]

20. Dimobe, K.; Wala, K.; Batawila, K.; Dourma, M.; Woegan, Y.A. Analyse spatiale des différentes formes de pressions anthropiques dans la réserve de faune de l'Oti- Mandouri (Togo). VertigO_La Revue Électronique en Sciences de l'Environnement 2012, 14, 1-22. (In French) [CrossRef]

21. Cohen, J.E. Human population: The next half century. Science 2003, 302, 1172-1175. [CrossRef]

22. United Nations. World Population Prospects: The Revision, Key Findings and Advance Tables; Working Paper No., ESA/P/WP/; Population Division, Ed.; Department of Economic and Social Affairs: New York, NY, USA, 2017; 248p.

23. Finn, H.C.; Stephens, N.S. The invisible harm: Land clearing is an issue of animal welfare. Wildl. Res. 2017, 44, 377-391. [CrossRef]

24. Baillie, J.E.; Hilton-Taylor, C.; Stuart, S.N. IUCN Red List of Threatened Species: A Global Species Assessment; IUCN: Gland, Switzerland; Cambridge, UK, 2004; 191p.

25. Foreman, D. Rewilding North America; Island Press: Washington, DC, USA, 2004; 312p.

26. International Union for Conservation of Nature (IUCN). Red List of Threatened Species. Gland, Switzerland: The World Conservation Union. 2006. Available online: https:/ / www.iucnredlist.org (accessed on 1 April 2006).

27. International Union for Conservation of Nature (IUCN). Red List of Threatened Species (Gland, Switzerland: International Union for Conservation of Nature, 1999). 2011. Available online: http:/ / www.iucnredlist.org (accessed on 31 December 2011 ).

28. Brummitt, N.A.; Bachman, S.P.; Griffiths-Lee, J.; Lutz, M.; Moat, J.F.; Farjon, A.; Aletrari, E. Green plants in the red: A baseline global assessment for the IUCN sampled Red List Index for plants. PLoS ONE 2015, 10, e0135152. [CrossRef] 
29. Qin, H.; Yang, Y.; Dong, S.; He, Q.; Jia, Y.; Zhao, L.; Xiang, J. Threatened species list of China's higher plants. Biodivers. Sci. 2017, 25, 696. [CrossRef]

30. McKinney, M.L.; Lockwood, J.L. Biotic homogenization: A few winners replacing many losers in the next mass extinction. Trends Ecol. Evol. 1999, 14, 450-453. [CrossRef]

31. Hunter, P. The human impact on biological diversity: How species adapt to urban challenges sheds light on evolution and provides clues about conservation. EMBO Rep. 2007, 8, 316-318. [CrossRef]

32. Mack, R.N.; Simberloff, D.; Lonsdale, W.M.; Evans, H.; Clout, M.; Bazzaz, F.A. Biotic invasions: Causes, epidemiology, global consequences, and control. Ecol. Appl. 2000, 10, 689-710. [CrossRef]

33. Kassem, H.S.; Bello, A.R.S.; Alotaibi, B.M.; Aldosri, F.O.; Straquadine, G.S. Climate change adaptation in the delta Nile Region of Egypt: Implications for agricultural extension. Sustainability 2019, 11, 685. [CrossRef]

34. Turner, B.L., II; Lambin, E.F.; Reenberg, A. From the cover land change science special feature: The emergence of land change science for global environmental change and sustainability. Proc. Natl. Acad. Sci. USA 2007, 104, 20666-20671. [CrossRef]

35. Benzer, N. Using the geographical information system and remote sensing techniques for soil erosion assessment. Pol. J. Environ. Stud. 2010, 19, 881-886.

36. Zhang, X.; Hu, Y.; Zhuang, D.; Qi, Y.; Ma, X. Ndvi spatial pattern and its differentiation on the Mongolian plateau. J. Geogr. Sci. 2009, 19, 403-415. [CrossRef]

37. Kaspersen, P.S.; Fensholt, R.; Huber, S. A spatiotemporal analysis of climatic drivers for observed changes in Sahelian vegetation productivity (1982-2007). Int. J. Geophys. 2011, 2011, 715321. [CrossRef]

38. Hope, A.S.; Boynton, W.L.; Stow, D.A.; Douglas, D.C. Interannual growth dynamics of vegetation in the kuparuk river watershed, alaska based on the normalized difference vegetation index. Int. J. Remote Sens. 2003, 24, 3413-3425. [CrossRef]

39. Rhyma, P.P.; Norizah, K.; Hamdan, O.; Faridah-Hanum, I.; Zulfa, A.W. Integration of normalised different vegetation index and Soil-Adjusted Vegetation Index for mangrove vegetation delineation. Remote Sens. Appl. Soc. Environ. 2020, 17, 100280. [CrossRef]

40. Ren, H.; Zhou, G.; Zhang, F. Using negative soil adjustment factor in soil-adjusted vegetation index (SAVI) for aboveground living biomass estimation in arid grasslands. Remote Sens. Environ. 2018, 209, 439-445. [CrossRef]

41. Senseman, G.M.; Bagley, C.F.; Tweddale, S.A. Correlation of rangeland cover measures to satellite-imagery-derived vegetation indices. Geocarto Int. 1996, 11, 29-38. [CrossRef]

42. Ahmad, F. Spectral vegetation indices performance evaluated for Cholistan Desert. J. Geogr. Reg. Plan. $2012,5,165-172$.

43. Seleem, T.A.; Aboulela, H.A. Seismicity and geologic structures indubitable in Wadi Hagul, north Eastern Desert, Egypt. Int. J. Geosci. 2011, 2, 55. [CrossRef]

44. Zahran, M.A.; Willis, A.J. The Vegetation of Egypt, 2nd ed.; Springer: Dordrecht, The Netherlands, 2009; 437p.

45. Abbas, N.H.; ELAraby, M.M.; Ahmad, H.F.; ELSherbeny, E.A. Molecular insight into Wadi Hagul rare diversity: Echinops spinosus and fagonia molis, plant species. Egypt. J. Genet. Cytol. 2021, 50, 83-94.

46. Boulos, L. Flora of Egypt: Azollaceae-Oxalidaceae; Al-Hadara Publishing: Cairo, Egypt, 1999; Volume I, 419p.

47. Boulos, L. Flora of Egypt: Geraniaceae-Boraginaceae; Al-Hadara Publishing: Cairo, Egypt, 2000; Volume II, 352p.

48. Boulos, L. Flora of Egypt: Verbenaceae-Compositae); Al-Hadara Publishing: Cairo, Egypt, 2002; Volume III, 373p.

49. Boulos, L. Flora of Egypt: Monocotyledons (Alismataceae-Orchidaceae); Al-Hadara Publishing: Cairo, Egypt, 2005; Volume IV, 617p.

50. Boulos, L. Flora of Egypt Checklist, Revised Annotated ed.; Al-Hadara Publishing: Cairo, Egypt, 2009; 410p.

51. Raunkiaer, C. The Plant Life Forms and Statistical Plant Geography; Clarendon Press: Oxford, UK, 1934; 632p.

52. Tutin, T.G.; Heywood, V.H.; Burges, N.A.; Moore, M.D.; Valentine, D.H.; Walters, S.M.; Webb, D.A. Flora Europaea; Cambridge University Press: Cambridge, UK, 1964; Volumes 1-5.

53. Davis, P.H. Flora of Turkey and the East Aegean Islands; Edinburgh University Press: Edinburgh, UK, 1965-1985; Volumes 1-9.

54. Estefan, G.; Sommer, R.; Ryan, J. Methods of Soil, Plant, and Water Analysis: A Manual for the West Asia and North Africa Region; International Center for Agricultural Research in the Dry Areas: Beirut, Lebanon, 2013; 243p.

55. Page, A.L.; Miller, R.H.; Keeney, D.R. Methods of Soil Analysis, Part 2: Chemical and Microbiological Properties; American Society of Agronomy: Madison, WI, USA, 1982; 1159p.

56. Jackson, M.L. Soil Chemicals Analysis; Prentice-Hall of India Private: New Delhi, India, 1967; 498p.

57. Piper, C.S. Soil and Plant Analysis; University of Adelaide: Adelaide, Australia, 1950; 368p.

58. McCune, B.; Mefford, M.J. PCORD for Windows: Multivariate Analysis of Ecological Data; Version 4.14. User's Guide; MjM Software: Gleneden Beach, OR, USA, 1999; 47p.

59. ter Braak, C.J.F. CANOCO-an extension of DECORANA to analyze species-environment relationships. Plant Ecol. 1988, 75, 159-160. [CrossRef]

60. Abdelaal, M. Current status of the floristic composition in Wadi Hagul, northwest Suez gulf, Egypt. Rendiconti Lincei 2016, 28, 81-92. [CrossRef]

61. Marie, A. A Model for the Use of GIS in Vegetation Mapping of a Phytogeographical Region in Egypt. Ph.D. Thesis, Faculty of Science Al-Azhar University, Cairo, Egypt, 2000; 206p.

62. Salama, F.M.; Sayed, S.A.; Abd Abd EL-Gelil, A.A. Plant communities and floristic composition of the vegetation of Wadi Al-Assiuty and Wadi Habib in the Eastern Desert, Egypt. Not. Sci. Biol. 2014, 6, 196-206. [CrossRef]

63. Aronson, J.A. HALOPHA: A Data Base of Salt Tolerant Plants of the World; Whitehead, E.E., Ed.; Office of Arid Land Studies, University of Arizona: Tuscon, AZ, USA, 1989; 77p. 
64. Täckholm, V. Students' Flora of Egypt, 2nd ed.; Cooperative Printing Company: Cairo, Egypt, 1974.

65. Mashaly, I.A. On the phytosociology of Wadi Hagul, Red Sea coast. Egypt. J. Environ. Sci. 1996, 12, 31-54.

66. Martiny, N.; Camberlin, P.; Richard, Y.; Philippon, N. Compared regimes of NDVI and Rainfall in semi-arid regions of Africa. Int. J. Remote Sens. 2006, 27, 5201-5223. [CrossRef]

67. Parmesan, C.; Hanley, M.E. Plants and climate change: Complexities and surprises. Ann. Bot. 2015, 116, 849-864. [CrossRef]

68. Irl, S.D.H.; Obermeier, A.; Beierkuhnlein, C.; Steinbauer, M.J. Climate controls plant life-form patterns on a high-elevation oceanic island. J. Biogeogr. 2020, 47, 2261-2273. [CrossRef]

69. Pausata, F.S.R.; Gaetani, M.; Messori, G.; Berg, A.; Souza, D.M.D.; Sage, R.; Demenocal, P. The greening of the Sahara: Past changes and future implications. One Earth 2020, 2, 235-250. [CrossRef]

70. Nafus, M.G.; Tuberville, T.D.; Buhlmann, K.A.; Todd, B.D. Precipitation quantity and timing affect native plant production and growth of a key herbivore, the desert tortoise, in the Mojave Desert. Clim. Chang. Responses 2017, 4, 4. [CrossRef]

71. Ruhm, J.; Böhnert, T.; Weigend, M.; Merklinger, F.F.; Stoll, A.; Quandt, D.; Luebert, F. Plant life at the dry limit—Spatial patterns of floristic diversity and composition around the hyperarid core of the Atacama Desert. PLoS ONE 2020, 15, e0233729. [CrossRef]

72. Batanouny, K.H. Topography and plant life. In Plants in the Deserts of the Middle East; Batanouny, K.H., Ed.; Springer: Berlin/Heidelberg, Germany, 2001; pp. 25-29.

73. Wang, J.; Wang, H.; Cao, Y.; Bai, Z.; Qin, Q. Effects of soil and topographic factors on vegetation restoration in opencast coal mine dumps located in a loess area. Sci. Rep. 2016, 6, 22058. [CrossRef] [PubMed]

74. Baartman, J.E.M.; Temme, A.J.A.M.; Saco, P.M. The effect of landform variation on vegetation patterning and related sediment dynamics. Earth Surf. Process. Landf. 2018, 43, 2121-2135. [CrossRef]

75. Abd El-Galil, A. Floristic Composition and Eco Physiological Studies on Some Xerophytic Plants in Wadi El-Assiuty, Eastern Desert, Egypt. Master's Thesis, Faculty of Science Assiut University, Asyut, Egypt, 2014; 330p.

76. El-Amier, Y.A. Vegetation structure and soil characteristics of five common geophytes in desert of Egypt. Egypt. J. Basic Appl. Sci. 2016, 3, 172-186. [CrossRef]

77. Jafari, Z.; Kianian, M.; Aslani, F.; Akbarlo, M. Floristic composition, life forms and geographical distribution (case study: Lashgardar rangelands of Malayer, Iran). J. Environ. Sci. Technol. 2016, 9, 140-148. [CrossRef]

78. Al Shaye, N.A.; Masrahi, Y.S.; Thomas, J. Ecological significance of floristic composition and life forms of Riyadh region, Central Saudi Arabia. Saudi J. Biol. Sci. 2020, 27, 35-40. [CrossRef] [PubMed]

79. Galal, T.M.; Fahmy, A.G. Plant diversity and community structure of Wadi Gimal protected area, Red Sea Coast of Egypt. Afr. J. Ecol. 2012, 50, 266-276. [CrossRef]

80. Abbas, M.S.; Afefe, A.A.; Hatab, E.-B.E.; Gaber, E.-S.I. Vegetation-Soil Relationships in Wadi El-Rayan Protected Area, Western Desert, Egypt. Jordan J. Biol. Sci. 2016, 9, 97-107.

81. Bouallala, M.H.; Neffar, S.; Chenchouni, H. Vegetation traits are accurate indicators of how do plants beat the heat in dry lands: Diversity and functional traits of vegetation associated with water towers in the Sahara Desert. Ecol. Indic. 2020, 114, 106364. [CrossRef]

82. Mohler, C.L.; Liebman, M. Weed productivity and competition in sole crops and intercrops of barley and field pea. J. Appl. Ecol. 1987, 24, 685-699. [CrossRef]

83. Hurlbert, S. The non concept of species diversity: A critique and alternative parameters. Ecology 1971, 52, 577-586. [CrossRef]

84. Jost, L.; Chao, A. Diversity Analysis; Taylor \& Francis: Milton Keynes, UK, 2008.

85. Shaltout, S. Ecological Studies on the Alien Species in the Egyptian Flora. Master's Thesis, Faculty of Science Tanta University, Tanta, Egypt, 2014; 206p.

86. Assaeed, A.M.; Al-Rowaily, S.L.; El-Bana, M.I.; Hegazy, A.K.; Dar, B.A.; Abd-ElGawad, A.M. Functional traits plasticity of the invasive herb Argemone ochroleuca sweet in different arid habitats. Plants 2020, 9, 1268. [CrossRef] [PubMed]

87. Hegazy, A.K.; Soliman, M.I.; Mashaly, I.A. Perspectives on the biology of Heliotropium curassavicum in the Deltaic Mediterranean coast of Egypt. Arab Gulf J. Sci. Res. 1994, 12, 525-545.

88. Gupta, S.; Narayan, R. Phenotypic plasticity of Chenopodium murale across contrasting habitat conditions in peri-urban areas in Indian dry tropics: Is it indicative of its invasiveness? Plant Ecol. 2012, 213, 493-503. [CrossRef]

89. Herpigny, B.; Dassonville, N.; Ghysels, P.; Mahy, G.; Meerts, P. Variation of growth and functional traits of invasive knotweeds (Fallopia spp.) in Belgium. Plant Ecol. 2012, 213, 419-430. [CrossRef]

90. Abd-ElGawad, A.M.; El Gendy, A.E.-N.G.; Assaeed, A.M.; Al-Rowaily, S.L.; Omer, E.A.; Dar, B.A.; Al-Taisan, W.A.A.; Elshamy, A.I. Essential oil enriched with oxygenated constituents from invasive plant Argemone ochroleuca exhibited potent phytotoxic effects. Plants 2020, 9, 998. [CrossRef] [PubMed]

91. Abd El-Ghani, M.M.; Salama, F.; Salem, B.; El Hadidy, A.; Abdel-Aleem, M. Biogeographical relations of a hyper arid desert flora in Eastern Egypt. Afr. J. Ecol. 2014, 52, 173-191. [CrossRef] 